OPEN ACCESS

Edited by:

Raquel Esteban,

University of the Basque Country,

Spain

Reviewed by:

José Javier Peguero-Pina, Centro de Investigación y Tecnología Agroalimentaria de Aragón, Spain

Nancy Elizabeth Grulke, Western Wildlands Environmental Threats Assessment Center, Pacific

Northwest Research Station, US

Forest Service, United States

*Correspondence:

Lucia Guidi

Iucia.guidi@unipi.it

tThese authors have contributed equally to this work.

Specialty section: This article was submitted to Functional Plant Ecology, a section of the journal Frontiers in Plant Science

Received: 21 February 2017 Accepted: 29 May 2017

Published: 15 June 2017

Citation:

Cotrozzi L, Pellegrini E, Guidi L, Landi M, Lorenzini $G$, Massai $R$, Remorini $D$, Tonelli $M$, Trivellini $A$, Vernieri $P$ and Nali C (2017) Losing the Warning Signal: Drought

Compromises the Cross-Talk of Signaling Molecules in Quercus ilex Exposed to Ozone.

Front. Plant Sci. 8:1020. doi: 10.3389/fpls.2017.01020

\section{Losing the Warning Signal: Drought Compromises the Cross-Talk of Signaling Molecules in Quercus ilex Exposed to Ozone}

\author{
Lorenzo Cotrozzi ${ }^{1+}$, Elisa Pellegrini ${ }^{1+}$, Lucia Guidi ${ }^{1 *}$, Marco Landi', Giacomo Lorenzini ${ }^{1}$, \\ Rossano Massai ${ }^{1}$, Damiano Remorini ${ }^{1}$, Mariagrazia Tonelli ${ }^{1}$, Alice Trivellini ${ }^{2}$, \\ Paolo Vernieri ${ }^{1}$ and Cristina Nali ${ }^{1}$ \\ ${ }^{1}$ Department of Agriculture, Food and Environment, University of Pisa, Pisa, Italy, ${ }^{2}$ Institute of Life Sciences, Scuola \\ Superiore Sant'Anna, Pisa, Italy
}

Understanding the interactions between drought and acute ozone $\left(\mathrm{O}_{3}\right)$ stress in terms of signaling molecules and cell death would improve the predictions of plant responses to climate change. The aim was to investigate whether drought stress influences the responses of plants to acute episodes of $\mathrm{O}_{3}$ exposure. In this study, the behavior of 84 Mediterranean evergreen Quercus ilex plants was evaluated in terms of crosstalk responses among signaling molecules. Half of the sample was subjected to drought (20\% of the effective daily evapotranspiration, for 15 days) and was later exposed to an acute $\mathrm{O}_{3}$ exposure $\left(200 \mathrm{~nL} \mathrm{~L}^{-1}\right.$ for 5 h). First, our results indicate that in well-water conditions, $\mathrm{O}_{3}$ induced a signaling pathway specific to $\mathrm{O}_{3}$-sensitive behavior. Second, different trends and consequently different roles of phytohormones and signaling molecules (ethylene, ET; abscisic acid, ABA; salycilic acid, SA and jasmonic acid, JA) were observed in relation to water stress and $\mathrm{O}_{3}$. A spatial and functional correlation between these signaling molecules was observed in modulating $\mathrm{O}_{3}$-induced responses in well-watered plants. In contrast, in drought-stressed plants, these compounds were not involved either in $\mathrm{O}_{3}$-induced signaling mechanisms or in leaf senescence (a response observed in water-stressed plants before the $\mathrm{O}_{3}$-exposure). Third, these differences were ascribable to the fact that in drought conditions, most defense processes induced by $\mathrm{O}_{3}$ were compromised and/or altered. Our results highlight how $Q$. ilex plants suffering from water deprivation respond differently to an acute $\mathrm{O}_{3}$ episode compared to well-watered plants, and suggest new effect to be considered in plant responses to environmental changes. This poses the serious question as to whether or not multiple high-magnitude $\mathrm{O}_{3}$ events (as predicted) can change these cross-talk responses, thus opening it up possible further investigations.

Keywords: climate change, holm oak, mediterranean plant species, phytohormones, hypersensitive response, stress combination 


\section{INTRODUCTION}

Mediterranean plants are threatened by several abiotic stress factors [e.g., warming, drought, tropospheric ozone $\left(\mathrm{O}_{3}\right)$, UV radiation, salinity] due to environmental changes characterized by new types of stress conditions and stress combinations, which are expected to be more extreme in the Mediterranean than in other areas worldwide (Matesanz and Valladares, 2014; Gray and Brady, 2016; Guidi et al., 2017). Today, drought is the major factor limiting plant performance, and revealing the mechanisms that enable plants to survive or acclimatize to such conditions is crucial (Claeys and Inzé, 2013). On the other hand, $\mathrm{O}_{3}$ is by far the most phytotoxic air pollutant with deleterious effects on growth and productivity (Vainonen and Kangasjärvi, 2015; Cotrozzi et al., 2016a; Yang et al., 2016). Both drought and $\mathrm{O}_{3}$ are co-occurring, increasing stressors in future climate change scenarios (Bates et al., 2008). Given that high-level $\mathrm{O}_{3}$ episodes and drought often occur together in Mediterranean areas, especially during the summer, their interaction needs to be understood (Iyer et al., 2013; Cotrozzi et al., 2016b). $\mathrm{O}_{3}$ enters the leaf through open stomata, then drought-triggered stomatal closure limits $\mathrm{O}_{3}$ uptake, thereby limiting foliar damage (Panek et al., 2002). However, other studies have highlighted that these factors have a synergistic effect, with increased $\mathrm{O}_{3}$ sensitivity observed in droughted plants (Alonso et al., 2014; Pollastrini et al., 2014). The response of plants to a combination of stresses is species-specific and depends on the intensity and duration of each stress factor (Ramegowda and Senthil-Kumar, 2015).

Plant exposure to acute $\mathrm{O}_{3}$ (high $\mathrm{O}_{3}$ concentration within a short period) commonly occurs during hot, dry Mediterranean summers (Matesanz and Valladares, 2014), which often results in a programmed cell death (PCD) response. This is a physiological process that selectively targets and eliminates unwanted cells in response to a variety of biotic and abiotic stimuli (Apel and Hirt, 2004). PCD resembles the hypersensitive response (HR) observed in several plant-pathogen interactions, which often precedes the acquisition of a systemic resistance by plants (Kangasjärvi et al., 1994; Rao et al., 2000; Pellegrini et al., 2013; Vainonen and Kangasjärvi, 2015; Pellegrini et al., 2016). $\mathrm{O}_{3}$ entering the leaves first induces a biphasic oxidative burst with a massive, rapid and transient increase in apoplastic reactive oxygen species (ROS), which is the main event leading to PCD activation (Langebartels et al., 2002) Similarly, an oxidative burst was usually observed in plants under drought (Smirnoff, 1993; Miller et al., 2010; Noctor et al., 2014) and the drought-triggered ROS production can elicit acclimatory events (Smirnoff, 1993). However, HR-like response has never been observed following drought stress. Therefore, the role of ROS in cell signaling and in regulating gene expression is a key aspect (Baxter et al., 2014), in particular in plant, subjected to abiotic stresses, including $\mathrm{O}_{3}$ and drought (Wilkinson and Davies, 2010).

The signaling pathways activated by $\mathrm{O}_{3}$ are integrated into a complex regulatory system involving ROS, plant hormones [e.g., ethylene (ET) and abscisic acid (ABA)], signaling molecules [e.g., salicylic acid (SA) and jasmonic acid (JA)], and secondary messengers (e.g., $\mathrm{Ca}^{2+}$ ). Signaling and cell death in $\mathrm{O}_{3}$-exposed plants have been reviewed by several authors (e.g., Rao et al.,
2000; Rao and Davis, 2001; Kangasjärvi et al., 2005; Tamaoki, 2008; Vainonen and Kangasjärvi, 2015; Carmody et al., 2016; Pellegrini et al., 2016). Different plants use many hydraulic and chemical signals to tune their sensing of water deficit (Wilkinson and Davies, 2010). Thus, the interactions between drought and acute $\mathrm{O}_{3}$ stress in terms of signaling molecules and cell death need to be studied in depth in order to improve predictions of plant acclimation/adaptation strategies to climate change (Carmody et al., 2016). Signaling in acute $\mathrm{O}_{3}$ exposure has mainly been studied in the test plant Arabidopsis thaliana, however, few works have evaluated these mechanisms in tree species [e.g., on hybrid poplar, by Kock et al. (2000)].

To the best of our knowledge, no studies have assessed signaling molecules and cell death in Mediterranean tree species exposed to $\mathrm{O}_{3} \cdot \mathrm{O}_{3}$ can also be used as a non-invasive tool to mimic signaling pathways triggered by active apoplastic ROS formation induced by pathogens (Vainonen and Kangasjärvi, 2015), also enabling conclusions to be drawn on drought-biotic stress interactions. The responses of Mediterranean species to the interaction of drought and $\mathrm{O}_{3}$ have yet to be extensively investigated as shown by the scarce information available in the literature (Kurz et al., 1998; Vitale et al., 2008; Calderòn Guerrero et al., 2013; Alonso et al., 2014; Cotrozzi et al., 2016b), especially in relation to acute exposure to the pollutant.

Holm oak (Quercus ilex L.) is probably the most widely studied Mediterranean evergreen tree species which has been defined as 'drought-avoidant' and 'water saver' with regard to its ecophysiological behavior (Bussotti et al., 2002), although adverse impacts of drought have also been reported in this species (e.g., Gimeno et al., 2008; Cotrozzi et al., 2016b). This species has also been referred to as the most tolerant to $\mathrm{O}_{3}$ stress among several other Quercus species (Calatayud et al., 2011). In a previous study carried out by this research group (Cotrozzi et al., 2016b), Q. ilex subjected to drought (30\% of the effective daily evapotranspiration) and/or chronic $\mathrm{O}_{3}\left(80 \mathrm{~nL} \mathrm{~L}^{-1}, 5 \mathrm{~h} \mathrm{~d}^{-1}\right.$, for 77 consecutive days) showed that the major determinant was the water deficit; however, oxidative stress (revealed by a significant build-up of MDA by-products) occurred only when drought was applied with $\mathrm{O}_{3}$ (Cotrozzi et al., 2016b).

In the present study, we evaluated the behavior of $Q$. ilex saplings, subjected or not to drought, and later exposed to acute $\mathrm{O}_{3}$ exposure by characterizing different components of $\mathrm{O}_{3}$ stress signaling. Our aim was to answer the following questions: (i) can acute $\mathrm{O}_{3}$ exposure initiate an HR? (ii) What role do phytohormones and signaling molecules play in the perception and transduction of drought and/or $\mathrm{O}_{3}$ stress? (iii) Do drought conditions compromise/alter the signaling responses to acute $\mathrm{O}_{3}$ exposure?

\section{MATERIALS AND METHODS}

\section{Plant Material and Experimental Design}

Three-year old $Q$. ilex saplings grown under field conditions were potted in 6.5-L pots with growing medium containing a mixture of standard soil Einhetserde Topfsubstrat ED 63 (Sinntal-Altengronau, Germany) and sand (3.5:1, in volume), 
according to Cotrozzi et al. (2016b). Two weeks before the beginning of the $\mathrm{O}_{3}$ treatment, 42 plants (WS) received $20 \%$ of the effective daily evapotranspiration (calculated by the average 24-h weight loss of five well-watered plants), whereas another 42 plants (WW) were kept at field water capacity. The two groups of plants were then subdivided into four sets $\left(\mathrm{WW}-\mathrm{O}_{3}, \mathrm{WS}-\mathrm{O}_{3}\right.$, $\mathrm{WW}+\mathrm{O}_{3}, \mathrm{WS}+\mathrm{O}_{3} ; 21$ plants per set) and transferred into four controlled fumigation facilities (temperature $23 \pm 1^{\circ} \mathrm{C}$, relative humidity $85 \pm 5 \%$ and photon flux density of $530 \mu \mathrm{mol}$ photons $\mathrm{m}^{-2} \mathrm{~s}^{-1}$ at plant height provided by incandescent lamps with L/D 14:10 photoperiod; lights were switched on from 7:00 to 21:00 to simulate environmental light conditions).

$\mathrm{WW}-\mathrm{O}_{3}$ and $\mathrm{WS}-\mathrm{O}_{3}$ plants were randomly distributed into two chambers, whereas $\mathrm{WW}+\mathrm{O}_{3}$ and $\mathrm{WS}+\mathrm{O}_{3}$ plants were randomly distributed in the other two chambers. After one week of acclimation, $\mathrm{WW}+\mathrm{O}_{3}$ and $\mathrm{WS}+\mathrm{O}_{3}$ plants were exposed to an acute $\mathrm{O}_{3}$ stress $\left(200 \mathrm{~nL} \mathrm{~L}^{-1}, 5 \mathrm{~h} \mathrm{day}^{-1}\right.$, in the form of a square wave between the $2 \mathrm{nd}$ and the 7 th $\mathrm{h}$ of the light period). On the other hand, $\mathrm{WW}-\mathrm{O}_{3}, \mathrm{WS}-\mathrm{O}_{3}$ plants were maintained under charcoal-filtered air, in which the $\mathrm{O}_{3}$ concentration was less than $5 \mathrm{~nL} \mathrm{~L}^{-1}$. During the $\mathrm{O}_{3}$-exposure, environmental factors were maintained as reported above.

The $\mathrm{O}_{3}$ exposure was performed according to Lorenzini et al. (1994) with minor modifications to avoid pseudo-replications. At the end of the drought exposure, plant water status was evaluated. Photosynthetic parameters were measured at 0, 5, 24 and $48 \mathrm{~h}$ from the beginning of the $\mathrm{O}_{3}$ exposure (FBE, From the Beginning of Exposure). Five fully expanded mature leaves per plant per treatment were taken at $0,1,2,5,8$, and $24 \mathrm{~h} \mathrm{FBE}$, stored at $-20^{\circ} \mathrm{C}$ and subsequently used for chemical analyses, with the exception of ET determination, which was performed immediately. At the same measuring times, staining, and microscopic assays were also performed on fresh material.

\section{Water Status of Plants}

Pre-dawn leaf water potential $\left(\mathrm{PD} \Psi_{\mathrm{W}}\right)$ was measured on three plants per treatment (one fully expanded mature leaf per plant) with a pressure chamber (PMS model 600, PMS Instrument Company, Albany, OR, USA). On the very same plants, relative water content (RWC) was calculated (one fully expanded mature leaf per plant) as: RWC $(\%)=(\mathrm{FW}-\mathrm{DW}) /(\mathrm{TW}-\mathrm{DW}) \times 100$, where FW is the fresh weight, TW is the turgid weight after rehydrating samples for $24 \mathrm{~h}$, and DW is the dry weight after oven-drying samples at $85^{\circ} \mathrm{C}$ for $24 \mathrm{~h}$.

\section{Gas Exchange and Chlorophyll a Fluorescence Measurements}

Gas exchange and chlorophyll $a$ fluorescence measurements were determined between 10:00 and 13:00 (solar time) on one fully expanded mature leaf per plant, on three plants per treatment. $\mathrm{CO}_{2}$ assimilation rate (A), stomatal conductance to water vapor $\left(g_{\mathrm{s}}\right)$ and intercellular $\mathrm{CO}_{2}$ concentration $\left(C_{\mathrm{i}}\right)$ in light-saturated conditions and ambient $\mathrm{CO}_{2}$ concentration were measured using an Infrared Gas Analyzer (LI-COR Inc., Lincoln, NE, United States) as reported by Cotrozzi et al. (2016b). Modulated chlorophyll $a$ fluorescence of photosystem II (PSII) was measured with a PAM-2000 fluorometer (Walz, Effeltrich, Germany) on the same leaves used for the gas exchange after 40 min of dark adaptation using a dark leaf clip provided by the producer. The maximal PSII photochemical efficiency $\left[F_{\mathrm{v}} / F_{m}=\left(F_{m^{-}}\right.\right.$ $\left.\left.F_{0}\right) / F_{m}\right]$ and the photochemical efficiency in light conditions $\left.\left[\Phi_{\text {PSII }}=\left(F_{m}{ }^{\prime}-F_{\mathrm{S}}\right) / F_{m}{ }^{\prime}\right)\right]$ were calculated (Genty et al., 1989). Maximal fluorescence, $F_{m}$, when all PSII reaction centers were closed, was determined by applying a saturating light pulse $(0.8 \mathrm{~s})$ at $8,000 \mu \mathrm{mol} \mathrm{m} \mathrm{m}^{-2} \mathrm{~s}^{-1}$ in dark-adapted leaves. Fluorescence was induced with actinic light (about $480 \mu \mathrm{mol} \mathrm{m} \mathrm{m}^{-2} \mathrm{~s}^{-1}$ ), superimposed with $800 \mathrm{~ms}$ saturating pulses $\left(10,000 \mu \mathrm{mol} \mathrm{m}^{-2}\right.$ $\mathrm{s}^{-1}$ ) at $20 \mathrm{~s}$ intervals to determine maximal fluorescence in the light-adapted state $\left(F_{m}^{\prime}\right)$. Minimal fluorescence in the lightadapted state $\left(F_{0}^{\prime}\right)$ was determined immediately after turning off the actinic source in the presence of a far-red $(>710 \mathrm{~nm})$ background for $10 \mathrm{~s}$ to ensure maximal oxidation of PSII electron acceptors. The saturation pulse method was used to analyze the quenching components, as described by Schreiber et al. (1986).

\section{Staining and Microscopic Assays}

For the detection of dead cells, Evan's blue staining was used according to Tonelli et al. (2015). Leaf material was boiled for $1 \mathrm{~min}$ in a mixture of phenol, lactic acid, glycerol and distilled water (1:1:1:1, in vol.) containing $20 \mathrm{mg} \mathrm{mL}^{-1}$ Evan's blue and, after clarification with an aqueous chloral hydrate solution, examined under a light microscope (DM 4000 B, Leica, Wetzlar, Germany). To detect $\mathrm{H}_{2} \mathrm{O}_{2}$ accumulation, fresh leaf samples were stained with 3,30-diaminobenzidine (DAB) following Tonelli et al. (2015). Leaf parts were incubated for at least $8 \mathrm{~h}$ in a DAB solution $\left(1 \mathrm{mg} \mathrm{mL}^{-1}\right)$ in $\mathrm{HCl}$ adjusted to $\mathrm{pH}$ 5.6. The samples were then soaked in $70 \%(\mathrm{v} / \mathrm{v})$ boiling ethanol and clarified overnight in a solution of $2.5 \mathrm{~g} \mathrm{~L}^{-1}$ aqueous chloral hydrate solution. The cellular $\mathrm{H}_{2} \mathrm{O}_{2}$ accumulation was visualized under a light microscope as a reddish-brown precipitation.

\section{ROS determination}

$\mathrm{H}_{2} \mathrm{O}_{2}$ production was measured using the Amplex Red Hydrogen Peroxide/Peroxidase Assay Kit (Molecular Probes, Invitrogen, Carlsbad, CA, United States), according to Pellegrini et al. (2013). Spectrofluorimetric determinations were performed with a fluorescence/absorbance microplate reader (Victor3 1420 Multilabel Counter Perkin Elmer, Waltham, MA, United States) at 530 and $590 \mathrm{~nm}$ (excitation and emission resorufin fluorescence, respectively). $\mathrm{O}_{2}{ }^{-}$concentration was measured according to Tonelli et al. (2015), after extraction with a Tris- $\mathrm{HCl}$ buffer ( $50 \mathrm{mM}, \mathrm{pH} 7.5)$, with a spectrophotometer (6505 UV-Vis, Jenway, United Kingdom) at $470 \mathrm{~nm}$, and using a buffer solution as a blank.

\section{Phytohormone and Signaling Molecule Bioassays}

Two minutes after excision, ET production was measured by enclosing six intact leaves (cut a few millimeters below the petiole by a scalpel) in air-tight glass containers $(80 \mathrm{~mL})$. Gas samples $(2 \mathrm{~mL})$ were taken from the headspace of containers after $1 \mathrm{~h}$ incubation at room temperature. Separations were 
performed with a gas chromatograph (HP5890, Hewlett-Packard, Ramsey, MN, United States) equipped with a stainless steel column $(150 \times 0.4 \mathrm{~cm}$ i.d. packed with Hysep $\mathrm{T})$ and a flame ionization detector. Analytical conditions were as follows: injector and transfer line temperature at 70 and $350^{\circ} \mathrm{C}$, respectively, and carrier gas nitrogen at $30 \mathrm{~mL} \mathrm{~min}^{-1}$ (Pellegrini et al., 2013). SA was determined according to Vitti et al. (2016) with some minor modifications. High performance liquid chromatography (HPLC) separations were performed with a liquid chromatograph (Dionex, Sunnyvale, CA, United States) equipped with a reverse-phase Dionex column (Acclaim 120, C18 $5 \mu \mathrm{m}$ particle size, $4.6 \mathrm{~mm}$ i.d. $\times 150 \mathrm{~mm}$ length) and RF 2000 Fluorescence Detector. Analytical conditions were as follows: excitation and emission at 305 and $407 \mathrm{~nm}$, respectively, mobile phase containing $0.2 \mathrm{M}$ sodium acetate buffer, $\mathrm{pH}$ $5.5(90 \%)$ and methanol (10\%), and the flow-rate at $0.8 \mathrm{~mL}$ $\min ^{-1}$. JA was determined according to Pellegrini et al. (2013). HPLC separations were performed with the Dionex column described above and a UVD 170U UV/VIS detector. Analytical conditions were as follows: absorbance at $210 \mathrm{~nm}$, mobile phase containing $0.2 \%(\mathrm{v} / \mathrm{v})$ acidified water, and the flowrate at $1 \mathrm{~mL} \mathrm{~min}{ }^{-1}$. $\mathrm{ABA}$ was measured after extraction in distilled water (water:tissue ratio, 10:1) overnight at $4^{\circ} \mathrm{C}$. The indirect ELISA determinations, based on the use of DBPA1 monoclonal antibody, raised against $\mathrm{S}(+)-\mathrm{ABA}$, as described by Trivellini et al. (2011), were performed at $415 \mathrm{~nm}$ with a microplate reader (MDL 680, Perkin-Elmer, Waltham, MA, United States).

\section{Proline Content}

Proline content was measured as reported in Cotrozzi et al. (2016b), after extraction with sulfosalicylic acid (3\%, v/v). Spectrophotometric determinations were performed at $520 \mathrm{~nm}$, using toluene as a blank.

\section{Statistical Analysis}

Three repeated experiments were set up following a randomized design and the experimental plot consisted of one plant per container. Ecophysiological and biochemical measurements were carried out on three replicates for each treatment. The normality of data was preliminary tested by the Shapiro-Wilk $W$ test. The effects of drought exposure vs. well-watering were analyzed by the Student's $t$-test. The effects of $\mathrm{O}_{3}$ on ecophysiological parameters were tested using one-way repeated measures ANOVA with treatment $\left(\mathrm{WW}+\mathrm{O}_{3}, \mathrm{WS}+\mathrm{O}_{3}\right)$ as the variability factor. The effects of $\mathrm{O}_{3}$ on biochemical parameters were evaluated by two-way ANOVA with treatment and time as variability factors. For both ecophysiological and biochemical analyses, Fisher's LSD was used as the post-test, with a significance level of $P \leq 0.05$. Since data obtained by control plants maintained in filtered air $\left(\mathrm{WW}-\mathrm{O}_{3}\right.$ and $\mathrm{WS}-\mathrm{O}_{3}$ ) did not show significant differences during the time course (data not shown), a comparison among means was carried out using as $\mathrm{WW}+\mathrm{O}_{3}$ and $\mathrm{WS}+\mathrm{O}_{3}$ plants controls before beginning the fumigation. Analyses were performed by NCSS 2000 Statistical Analysis System Software (Kaysville, UT, United States).

\section{RESULTS}

\section{Effects of Drought Stress}

After 15 days of drought, plants did not show visible foliar injury. Physiological responses are reported in Table 1. In WS plants, $\mathrm{PD}_{\mathrm{W}}$ decreased significantly to $-4.0 \mathrm{MPa}$ at the end of water deprivation compared to WW controls $(-0.5 \mathrm{MPa})$. However, no changes in RWC were recorded in WS leaves. The net carbon gain was reduced by about $73 \%$ in response to drought, which was a larger effect compared with the reduction of $g_{s}(-50 \%)$. Values of $C_{\mathrm{i}}$ increased in WS leaves $(+7 \%)$. Chlorophyll fluorescence measurements revealed a reduction in $\Phi_{\text {PSII }}(-39 \%)$ and $\mathrm{qP}$ $(-18 \%)$ in WS compared to WW leaves, but no changes in the $F_{\mathrm{v}} / F_{m}$ ratio. An increase of qNP $(+30 \%)$ was found after drought stress.

The biochemical responses at the end of drought exposure are summarized in Table 2. In comparison to the controls, $\mathrm{H}_{2} \mathrm{O}_{2}$ levels did not change in WS leaves, while accumulation of $\mathrm{O}_{2}{ }^{-}$was 1.6-fold higher under drought. A strong increase in

TABLE 1 | Water status and ecophysiological parameters in Quercus ilex plants well-watered (WW) or water stressed (20\% of the effective evapotranspiration daily for 15 days, WS).

\begin{tabular}{|c|c|c|c|c|}
\hline & & WW & WS & $P$ \\
\hline PDIW & $(-\mathrm{MPa})$ & $0.5 \pm 0.06$ & $4.0 \pm 0.70$ & $* *$ \\
\hline RWC & (\%) & $86 \pm 7.4$ & $82 \pm 1.7$ & ns \\
\hline A & $\left(\mu \mathrm{mol} \mathrm{CO} 2 \mathrm{~m}^{-2} \mathrm{~s}^{-1}\right)$ & $7.4 \pm 0.23$ & $2.0 \pm 0.13$ & $* * *$ \\
\hline$g_{s}$ & $\left(\mathrm{~mol} \mathrm{H}_{2} \mathrm{O} \mathrm{m}^{-2} \mathrm{~s}^{-1}\right)$ & $0.16 \pm 0.001$ & $0.08 \pm 0.008$ & $* * *$ \\
\hline $\mathrm{C}_{\mathrm{i}}$ & $\left(\mu \mathrm{mol} \mathrm{CO} \mathrm{mol}^{-1}\right)$ & $284 \pm 2.1$ & $304 \pm 8.1$ & $*$ \\
\hline $\mathrm{F}_{\mathrm{v}} / \mathrm{F}_{m}$ & & $0.83 \pm 0.003$ & $0.84 \pm 0.004$ & ns \\
\hline$\Phi_{P S I I}$ & & $0.36 \pm 0.008$ & $0.22 \pm 0.045$ & $* *$ \\
\hline qP & & $0.60 \pm 0.008$ & $0.49 \pm 0.034$ & $* *$ \\
\hline qNP & & $0.64 \pm 0.027$ & $0.83 \pm 0.043$ & $* *$ \\
\hline
\end{tabular}

Data are shown as mean \pm standard deviation. Asterisks show the significance of Student's t-test: ${ }^{* * *} P \leq 0.001,{ }^{* *} P \leq 0.01,{ }^{*} P \leq 0.05$, ns $P>0.05$. $\Phi_{P S I}$, photochemical efficiency in light conditions; $A, \mathrm{CO}_{2}$ assimilation rate; $\mathrm{Ci}$, intercellular $\mathrm{CO}_{2}$ concentration; $F_{v} / F_{m}$, potential PSIl photochemical efficiency; $g_{s}$, stomatal conductance to water vapor; $P D \Psi_{W}$, pre-dawn leaf water potential; $q P$, photochemical quenching coefficient; qNP, non-photochemical quenching coefficient; $R W C$, relative water content.

TABLE 2 | Biochemical parameters in Quercus ilex plants WW or water stressed (20\% of the effective evapotranspiration daily for 15 days, WS).

\begin{tabular}{|c|c|c|c|c|}
\hline & & WW & WS & $P$ \\
\hline $\mathrm{H}_{2} \mathrm{O}_{2}$ & $\left(\mu \mathrm{mol} \mathrm{g}{ }^{-1} \mathrm{DW}\right)$ & $0.18 \pm 0.011$ & $0.17 \pm 0.004$ & ns \\
\hline $\mathrm{O}_{2}^{-}$ & $\left(\mathrm{nmol} \min ^{-1} \mathrm{~g}^{-1} \mathrm{DW}\right)$ & $24.0 \pm 0.20$ & $38.7 \pm 1.47$ & $* * *$ \\
\hline ET & $\left(\mathrm{pl} \mathrm{g}^{-1} \mathrm{FW} \mathrm{h}^{-1}\right)$ & $136 \pm 15.0$ & $226 \pm 10.8$ & $* *$ \\
\hline SA & $\left(\mathrm{nmol} \mathrm{g} \mathrm{g}^{-1} \mathrm{DW}\right)$ & $7.1 \pm 1.04$ & $4.3 \pm 0.08$ & $* *$ \\
\hline JA & $\left(\mu \mathrm{mol} \mathrm{g}{ }^{-1} \mathrm{DW}\right)$ & $3.5 \pm 0.08$ & $24.0 \pm 0.35$ & $* * *$ \\
\hline ABA & $\left(\mathrm{nmol} \mathrm{g}{ }^{-1} \mathrm{DW}\right)$ & $4.2 \pm 0.03$ & $2.8 \pm 0.28$ & $* * *$ \\
\hline Pro & $\left(\mathrm{mmol} \mathrm{g}{ }^{-1} \mathrm{DW}\right)$ & $0.23 \pm 0.001$ & $0.32 \pm 0.010$ & $* * *$ \\
\hline
\end{tabular}

Data are shown as mean \pm standard deviation. Asterisks show the significance of Student t-test: ${ }^{* *} P \leq 0.001,{ }^{* *} P \leq 0.01$, ns $P>0.05$. ABA, abscisic acid; DW, dry weight; ET, ethylene; FW, fresh weight; $\mathrm{H}_{2} \mathrm{O}_{2}$, hydrogen peroxide; JA, jasmonic acid; $\mathrm{O}_{2}^{-}$, superoxide anion; Pro, proline; $\mathrm{SA}$, salicylic acid. 
Pro content $(+39 \%)$ was observed in WS leaves. The endogenous concentration of ABA and SA measured in WS leaves decreased significantly at the end of the experimental period $(-33 \%$ and $-39 \%$, respectively). However, the JA and ET amounts accumulated by WS leaves increased significantly (about 7-fold and $+66 \%$, respectively).

\section{Influence of Drought Stress on the Response to Acute $\mathrm{O}_{3}$ Exposure Macroscopic and Microscopic Ozone-Induced Symptoms}

At the end of the $\mathrm{O}_{3}$ treatment (alone and in combination with drought), leaves appeared macroscopically symptomless. However, $\mathrm{O}_{3}$-injuries were already detectable at the microscopic level after $5 \mathrm{~h} \mathrm{FBE}$, as confirmed by the appearance of dead cells observed in $\mathrm{WW}+\mathrm{O}_{3}$ and $\mathrm{WS}+\mathrm{O}_{3}$ (Figures 1A-D). Histological staining showed local accumulation of $\mathrm{H}_{2} \mathrm{O}_{2}$ evidenced by reddish-brown areas in $\mathrm{O}_{3}$-treated material (Figures $\mathbf{1 G}, \mathbf{H}$ ) (regardless of drought stress; Figures 1E,F).

\section{Ozone-Induced Physiological Responses}

The photosynthetic rate in light saturation conditions decreased strongly following $\mathrm{O}_{3}$ exposure in both $\mathrm{WW}+\mathrm{O}_{3}$ and $\mathrm{WS}+\mathrm{O}_{3}$ plants, and especially under drought $\left(-23\right.$ and $-41 \%$ in $\mathrm{WW}+\mathrm{O}_{3}$ and $\mathrm{WS}+\mathrm{O}_{3}$ plants, respectively) (Figure 2A). However, A values continued to decrease only in $\mathrm{WW}+\mathrm{O}_{3}$ leaves, also after the end of fumigation, reaching values of about $4 \mu \mathrm{mol} \mathrm{CO} \mathrm{CO}^{-2} \mathrm{~s}^{-1}$ at $48 \mathrm{~h} \mathrm{FBE}$ with a reduction of about $50 \%$ compared to the values determined before $\mathrm{O}_{3}$ exposure (Figure 2A). WS $+\mathrm{O}_{3}$ plants showed low levels of A already before the beginning of $\mathrm{O}_{3}$ exposure $(-73 \%$ in comparison with WW plants) and these values did not decrease further after the fumigation (Figure 2A). Ozone also induced a strong decrease in $g_{\mathrm{s}}$ in $\mathrm{WW}+\mathrm{O}_{3}$ and even more in $\mathrm{WS}+\mathrm{O}_{3}$ leaves at the end of the exposure $(-13$ and $-38 \%$ in $\mathrm{WW}+\mathrm{O}_{3}$ and $\mathrm{WS}+\mathrm{O}_{3}$ leaves, respectively) and the effect of $\mathrm{O}_{3}$ on $g_{\mathrm{s}}$ remained at 24 and $48 \mathrm{~h} \mathrm{FBE}$ (Figure 2B). However, in $\mathrm{WS}+\mathrm{O}_{3}$ plants, $g_{\mathrm{s}}$ values were $50 \%$ lower than those recorded in $\mathrm{WW}+\mathrm{O}_{3}$ plants. Finally, $\mathrm{C}_{\mathrm{i}}$ values increased significantly following $\mathrm{O}_{3}$ exposure in both $\mathrm{WW}+\mathrm{O}_{3}$ and $\mathrm{WS}+\mathrm{O}_{3}$ leaves $(+8 \%)$ although the values recorded in $\mathrm{WS}+\mathrm{O}_{3}$ leaves were significantly higher compared to those found in $\mathrm{WW}+\mathrm{O}_{3}$. In both $\mathrm{WW}+\mathrm{O}_{3}$ and $\mathrm{WS}+\mathrm{O}_{3}$ leaves, the $C_{\mathrm{i}}$ values reached at the end of the exposure were maintained up to the end of the experimental period, although a slight decrease was observed for $\mathrm{WW}+\mathrm{O}_{3}$ leaves at $24 \mathrm{~h} \mathrm{FBE}$ (Figure 2C).

Actual $\Phi_{\text {PSII }}$ decreased at the end of exposure in both $\mathrm{WW}+\mathrm{O}_{3}$ and $\mathrm{WS}+\mathrm{O}_{3}$ leaves ( -19 and $-62 \%$, respectively). However, $\Phi_{\text {PSII }}$ recovered completely $48 \mathrm{~h}$ FBE in both $\mathrm{WW}+\mathrm{O}_{3}$ and $\mathrm{WS}+\mathrm{O}_{3}$ leaves (Figure 2D). In $\mathrm{WW}+\mathrm{O}_{3}$ plants, $\mathrm{qP}$ values were higher than those observed before the beginning of exposure, both at 24 and $48 \mathrm{~h} \mathrm{FBE} \mathrm{(+19} \mathrm{and}+14 \%$, respectively) (Figure 2E). Conversely, in $\mathrm{WS}+\mathrm{O}_{3}$ plants, $\mathrm{qP}$ values decreased at the end of exposure $(-47 \%)$, but recovered completely from $24 \mathrm{~h}$ onward (Figure 2E). Values of qNP increased in $\mathrm{WW}+\mathrm{O}_{3}$ leaves at the end of the fumigation $(+24 \%)$, and similar values were maintained until $48 \mathrm{~h}$ FBE (Figure 2F). Conversely, in $\mathrm{WS}+\mathrm{O}_{3}$ plants, qNP decreased at 24 and $48 \mathrm{~h}$ FBE $(-14$ and $-8 \%$, respectively, in comparison with the pre-treatment values) (Figure 2F). These mechanisms were sufficient to protect PSII from photoinhibition given that the decrease in $F_{\mathrm{v}} / F_{m}$ observed at the end of exposure in both $\mathrm{WW}+\mathrm{O}_{3}$ and $\mathrm{WS}+\mathrm{O}_{3}$ leaves was completely recovered $48 \mathrm{~h}$ FBE (data not shown).
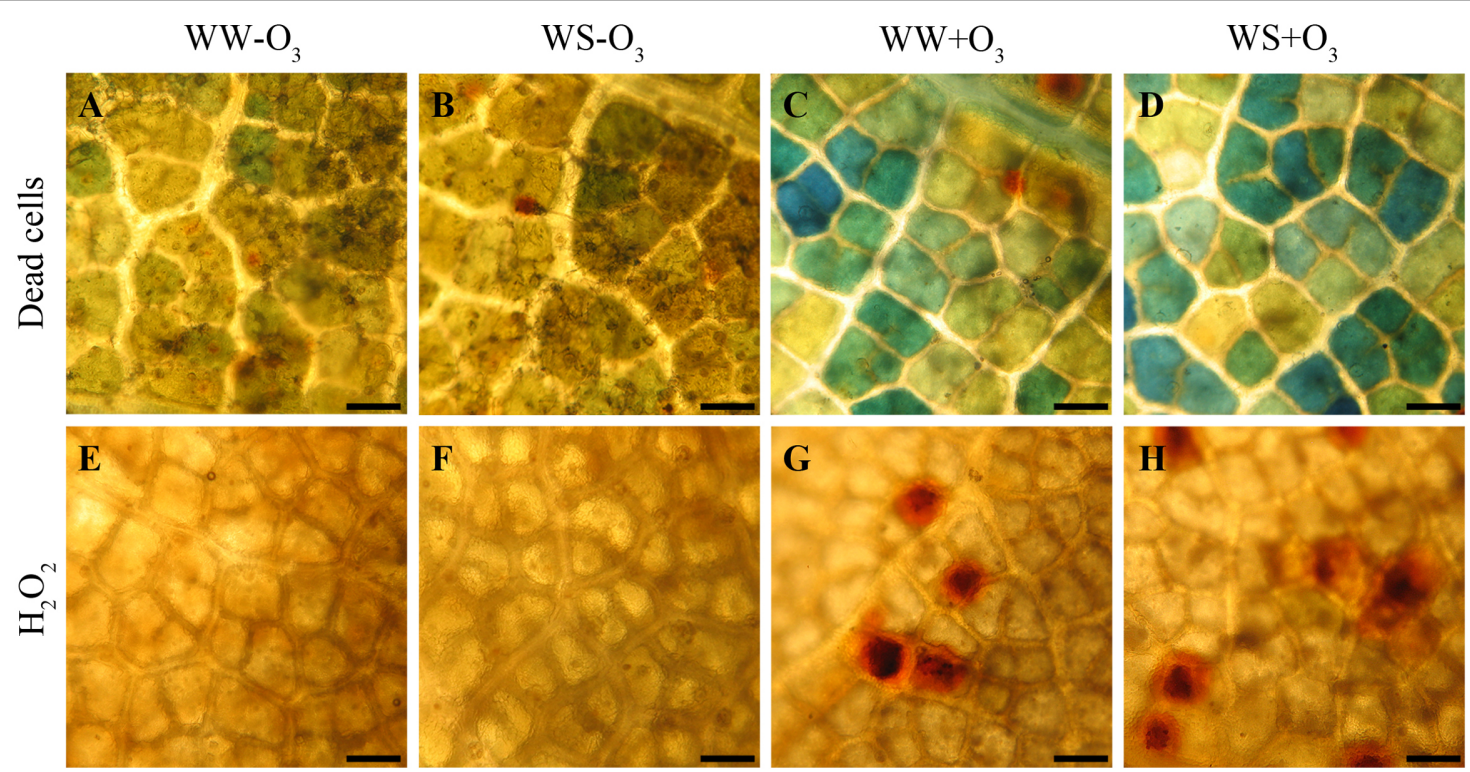

FIGURE 1 | Localization of dead cells visualized with Evans blue staining (A-D) and of hydrogen peroxide $\left(\mathrm{H}_{2} \mathrm{O}_{2}\right)$ visualized the $3,3^{\prime}$-diaminobenzidine (DAB) uptake method (E-H) in Quercus ilex leaves (i) well-watered (WW) and exposed to charcoal filtered air (WW-O $\mathrm{O}_{3}$ ); (ii) water stressed (20\% of effective evapotranspiration daily for 15 days) and exposed to charcoal filtered air $\left(\mathrm{WS}_{-} \mathrm{O}_{3}\right)$; (iii) well-watered and exposed to acute ozone $\left(200 \mathrm{~nL} \mathrm{L^{-1 }}\right.$ for $\left.5 \mathrm{~h}\right)\left(\mathrm{WW}_{+} \mathrm{O}_{3}\right)$; (iv) water stressed and $\mathrm{O}_{3}$ fumigated $\left(\mathrm{WS}+\mathrm{O}_{3}\right)$. The assays were performed $96 \mathrm{~h}$ FBE. Bars $50 \mu \mathrm{m}$. 

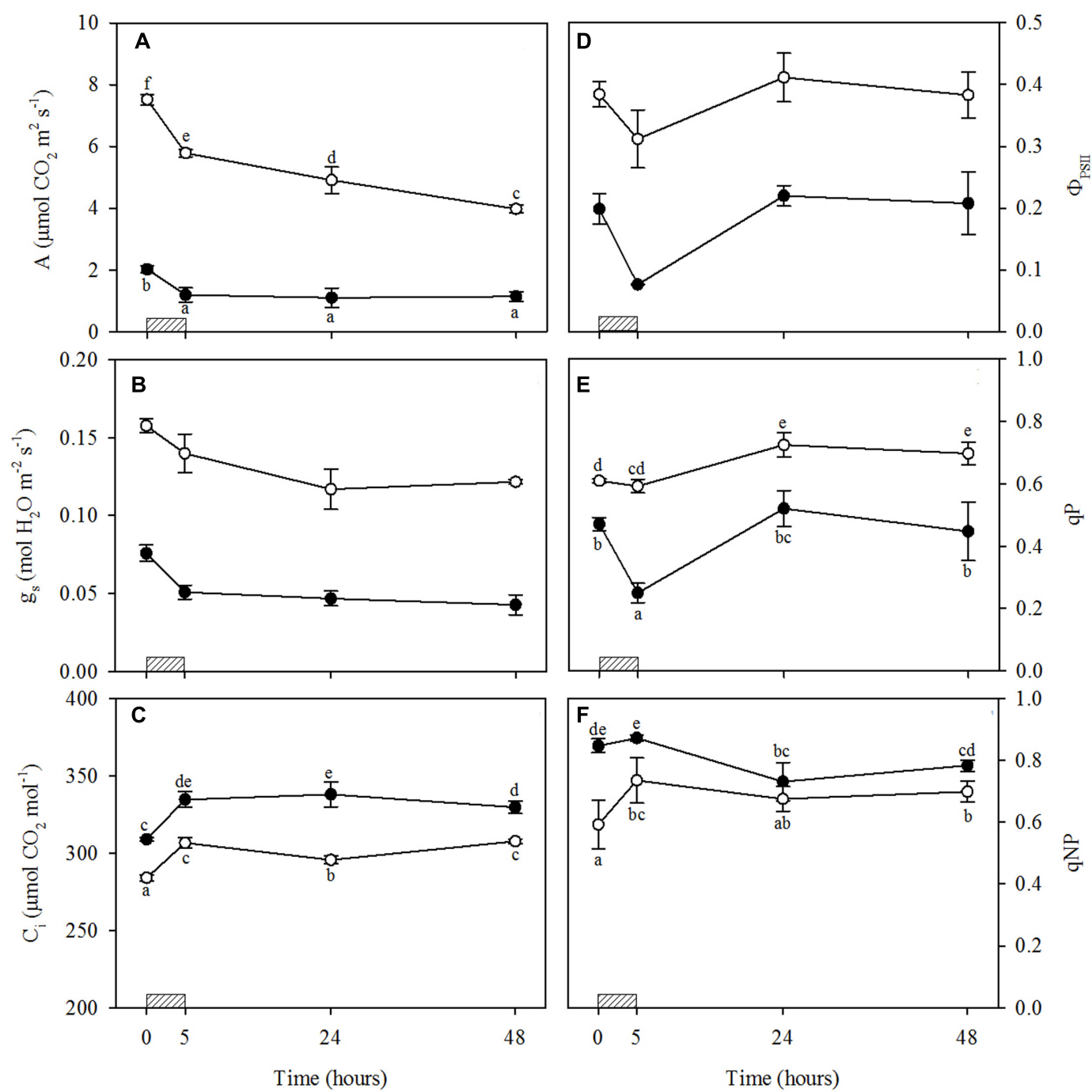

FIGURE 2 | Time course of leaf gas exchange and chlorophyll fluorescence parameters in Quercus ilex plants well-watered (open circle) or water stressed (20\% of the effective evapotranspiration daily for 15 days, closed circle) and exposed to acute ozone ( $200 \mathrm{~nL} \mathrm{~L}^{-1}$ for $5 \mathrm{~h}$ ). Data are shown as mean \pm standard deviation. The measurements were carried out 0, 5, 24 and $48 \mathrm{~h}$ from the beginning of exposure. According to the one-way repeated measures ANOVA with treatment as variability factor, different letters indicate significant differences $(P=0.05)$. The absence of letters in $B$ and $D$ indicates not significant interaction between variability

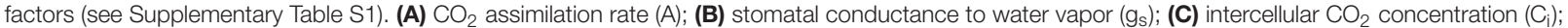
(D) photochemical efficiency in light conditions ( $\left.\Phi_{\mathrm{PSII}}\right)$; (E) photochemical quenching coefficient (qP); (F) non-photochemical quenching coefficient (qNP). The thick bottom line indicates the time ( $5 \mathrm{~h}$ ) of ozone exposure.

\section{Ozone-Induced ROS Accumulation}

A biphasic time course of $\mathrm{H}_{2} \mathrm{O}_{2}$ production in response to $\mathrm{O}_{3}$ was observed irrespective of drought stress (Figures $3 \mathrm{~A}$ and Supplementary Table S2). In both $\mathrm{WW}+\mathrm{O}_{3}$ and $\mathrm{WS}+\mathrm{O}_{3}$ plants, $\mathrm{H}_{2} \mathrm{O}_{2}$ content increased at $2 \mathrm{~h}$ FBE $(+33$ and $+43 \%$ as compared to time 0 , respectively), showed a significant decline at $5 \mathrm{~h} \mathrm{FBE}$, and increased again at $8 \mathrm{~h} \mathrm{FBE}$. This second peak was higher in $\mathrm{WW}+\mathrm{O}_{3}$ than in $\mathrm{WS}+\mathrm{O}_{3}$ plants $(+62 \%$ vs. $+38 \%$, compared to their respective time 0$)$. In addition, only in $\mathrm{WW}+\mathrm{O}_{3}$ leaves was the second peak higher than the first, and $\mathrm{H}_{2} \mathrm{O}_{2}$ levels at $24 \mathrm{~h}$ FBE remained higher than those at time 0 $(+24 \%)$.
The time patterns of $\mathrm{O}_{2}^{-}$induced by $\mathrm{O}_{3}$ were notably different in relation to water stress (Figures $\mathbf{3 B}$ and Supplementary Table S2). In $\mathrm{WW}+\mathrm{O}_{3}$ conditions, $\mathrm{O}_{2}^{-}$content also exhibited a clear biphasic time course. It peaked already at $1 \mathrm{~h}$ FBE $(+47 \%$, compared to the beginning of $\mathrm{O}_{3}$-exposure), and again at $8 \mathrm{~h}$ FBE $(+75 \%)$, although it remained higher than time 0 at 2 and $5 \mathrm{~h} \mathrm{FBE}\left(+20\right.$ and $+38 \%$, respectively). At $24 \mathrm{~h} \mathrm{FBE}$, the $\mathrm{O}_{2}^{-}$ content decreased at the same levels as time 0 . Conversely, in $\mathrm{WS}+\mathrm{O}_{3}$ plants (where $\mathrm{O}_{2}^{-}$levels were already higher in $\mathrm{WS}+\mathrm{O}_{3}$ than $\mathrm{WW}+\mathrm{O}_{3}$ plants), $\mathrm{O}_{2}^{-}$content decreased during the first two hours of $\mathrm{O}_{3}$ treatment $(-20$ and $-14 \%$, after 1 and $2 \mathrm{~h} \mathrm{FBE \text {, }}$ respectively). It then peaked at $5 \mathrm{~h} \mathrm{FBE}(+22 \%)$, decreased again 


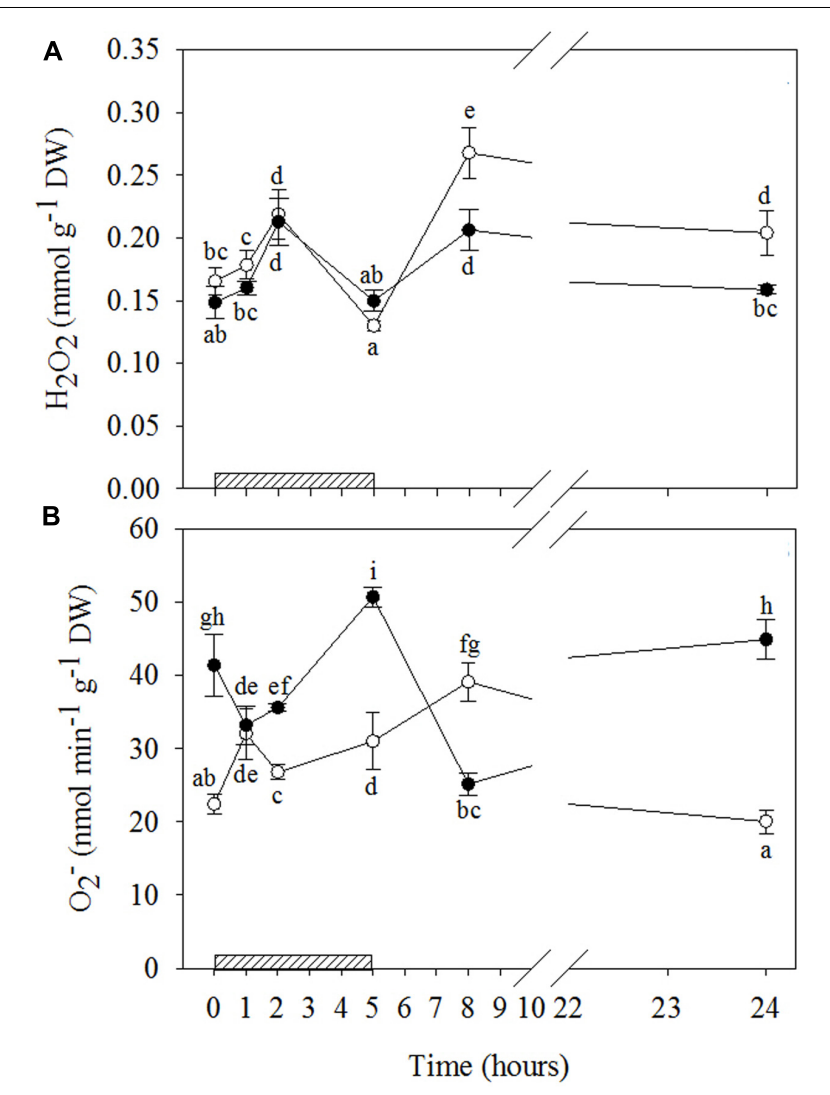

FIGURE 3 | Time course of reactive oxygen species (ROS) in Quercus ilex plants well-watered (open circle) or water stressed (20\% of the effective evapotranspiration daily for 15 days, closed circle) and exposed to acute ozone (200 $\mathrm{nL} \mathrm{L}{ }^{-1}$ for $5 \mathrm{~h}$ ). Data are shown as mean \pm standard deviation. The measurements were carried out at 0, 1, 2, 5, 8, and $24 \mathrm{~h}$ from the beginning of exposure. According to the two-way ANOVA with treatment and time as variability factors, different letters indicate significant differences $(P=0.05)$. DW, dry weight; $\mathrm{H}_{2} \mathrm{O}_{2}$, hydrogen peroxide (A); $\mathrm{O}_{2}^{-}$, superoxide anion (B). The thick bottom line indicates the time $(5 \mathrm{~h})$ of ozone exposure.

at $8 \mathrm{~h} \mathrm{FBE}$ (reaching the lowest values of the whole treatment), and finally increased again reaching the levels shown at time 0.

\section{Ozone-Induced Signaling Molecule Stimulation}

The results of signaling molecules indicate that $\mathrm{O}_{3}$ only significantly stimulated ET emission in $\mathrm{WW}+\mathrm{O}_{3}$ leaves (Figures 4A and Supplementary Table S2). In these plants, starting from $1 \mathrm{~h}$ of treatment onwards, ET emission values remained higher than those shown at the beginning of $\mathrm{O}_{3}$-exposure throughout the treatment period, and reached the maximum $8 \mathrm{~h} \mathrm{FBE}(+49,+52,+79,+128$, and $+76 \%$ after $1,2,5,8$, and $24 \mathrm{~h} \mathrm{FBE}$, respectively). Conversely, a clear biphasic time course of SA production was observed in response to $\mathrm{O}_{3}$, irrespective of drought stress. However, the average concentration throughout the treatment and the changes induced by $\mathrm{O}_{3}$ were higher and more pronounced in $\mathrm{WW}+\mathrm{O}_{3}$ than in $\mathrm{WS}+\mathrm{O}_{3}$ plants, respectively (Figures $4 \mathrm{~B}$ and Supplementary Table S2). In WW plants, total SA levels increased already at $1 \mathrm{~h} \mathrm{FBE}$, reaching their maximum values

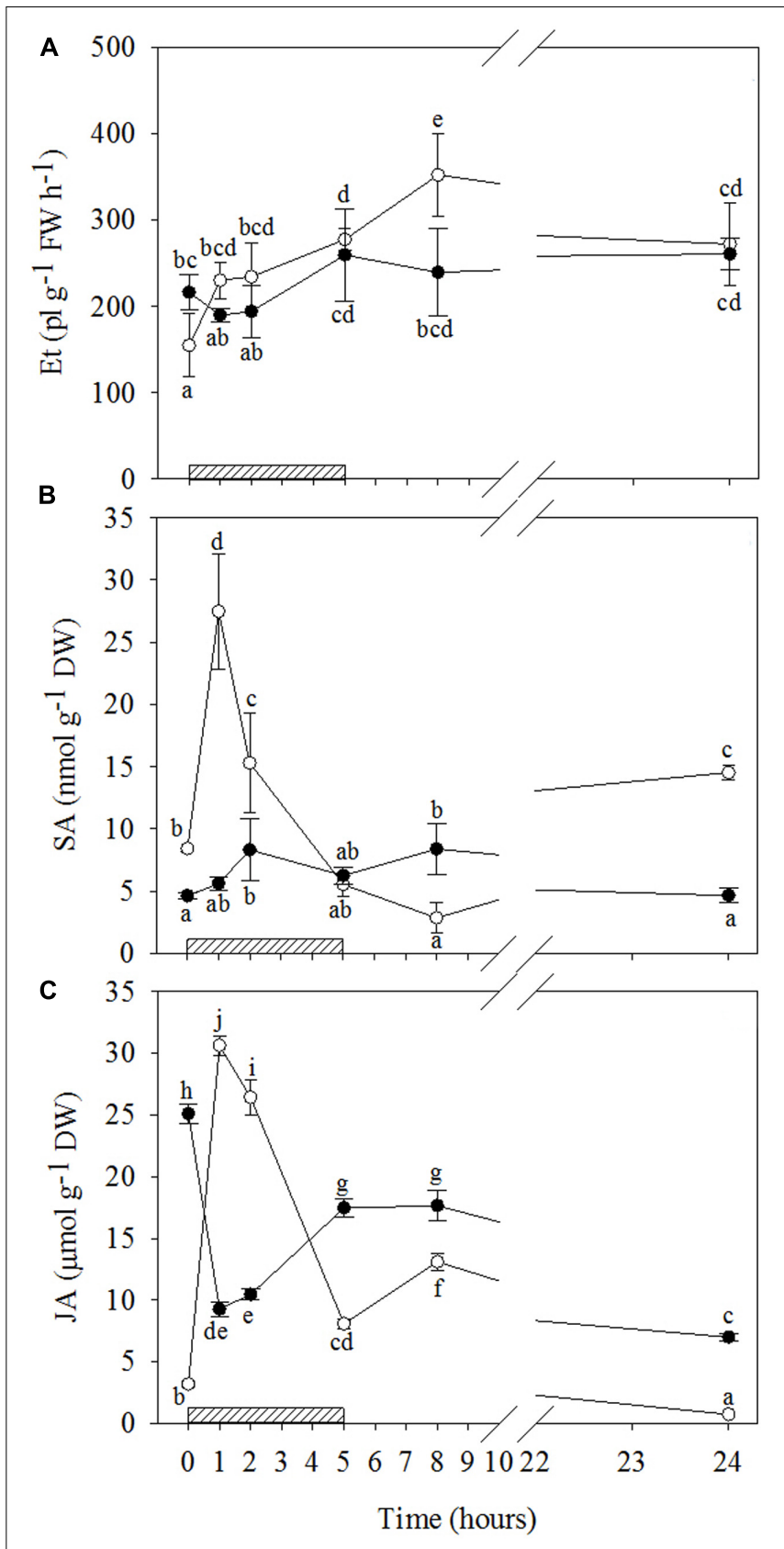

FIGURE 4 | Time course of phytohormones in Quercus ilex plants well-watered (open circle) or water stressed (20\% of the effective evapotranspiration daily for 15 days, closed circle) and exposed to acute ozone (200 $\mathrm{nL} \mathrm{L}^{-1}$ for $5 \mathrm{~h}$ ). Data are shown as mean \pm standard deviation. The measurements were carried out $0,1,2,5,8$, and $24 \mathrm{~h}$ from the beginning of exposure. According to the two-way ANOVA with treatment and time as variability factors, different letters indicate significant differences $(P=0.05)$. DW, dry weight; ET, ethylene (A); FW, fresh weight; JA, jasmonic acid (C); SA, salycilic acid (B). The thick bottom line indicates the time (5 h) of ozone exposure.

(three-fold higher than before the $\mathrm{O}_{3}$-treatment). They then progressively decreased to constitutive levels at $5 \mathrm{~h}$ FBE, and to even lower values at $8 \mathrm{~h} \mathrm{FBE}$, but increased again at the end 
of the experiment ( $+73 \%$ compared to time 0$)$. In $\mathrm{WS}+\mathrm{O}_{3}$ conditions, SA concentrations peaked at 2 and $8 \mathrm{~h} \mathrm{FBE} \mathrm{(+79} \mathrm{and}$ $+80 \%$, respectively), whereas SA levels were similar before the beginning of $\mathrm{O}_{3}$ treatment than at the other analysis times.

The time patterns of JA induced by $\mathrm{O}_{3}$ were also notably different in relation to drought (Figures 4C and Supplementary Table S2). A biphasic time course of JA production was shown by $\mathrm{WW}+\mathrm{O}_{3}$ plants. Similarly to $\mathrm{SA}$ (and ABA, as reported below), a first marked peak in JA levels (tenfold higher than controls) was shown by $\mathrm{WW}+\mathrm{O}_{3}$ plants at $1 \mathrm{~h}$ FBE. Then, JA progressively decreased until $5 \mathrm{~h} \mathrm{FBE}$ (remaining at higher levels than those recorded at time 0 ), peaked again $8 \mathrm{~h} \mathrm{FBE}$ (four times higher than time 0 ), and, finally, reached lower values than before the beginning of $\mathrm{O}_{3}$-treatment at $24 \mathrm{~h} \mathrm{FBE}$. Conversely, in WS $+\mathrm{O}_{3}$ plants (where JA levels, similarly to $\mathrm{O}_{2}{ }^{-}$, were already higher in $\mathrm{WS}+\mathrm{O}_{3}$ than $\mathrm{WW}+\mathrm{O}_{3}$ plants) a marked decrease in JA concentrations was observed starting from $1 \mathrm{~h}$ onwards (-63\%, in comparison to controls). Throughout the period of $\mathrm{O}_{3}$-treatment, the values of this phytohormone remained lower than those shown before the exposure, although a recovery was shown at 5 and $8 \mathrm{~h} \mathrm{FBE.}$

\section{Ozone-Induced ABA and Osmolyte Accumulation}

$\mathrm{O}_{3}$ significantly stimulated $\mathrm{ABA}$ production only in $\mathrm{WW}+\mathrm{O}_{3}$ leaves (Figures 5A and Supplementary Table S2), where a clear biphasic response to the pollutant was observed. In comparison to the levels shown before the $\mathrm{O}_{3}$ treatment, $\mathrm{ABA}$ in $\mathrm{WW}+\mathrm{O}_{3}$ leaves already increased at $1 \mathrm{~h} \mathrm{FBE}$ (overall three times), showed no differences at 2 and $5 \mathrm{~h} \mathrm{FBE}$, slightly increased again at $8 \mathrm{~h}$ FBE $(+44 \%)$ and, finally, reached lower values at $24 \mathrm{~h} \mathrm{FBE}$. In $\mathrm{WW}+\mathrm{O}_{3}$ conditions, $\mathrm{O}_{3}$ induced a slight increase in Pro only at the first two hours of exposure $(+46$ and $+33 \%$, respectively at 1 and $2 \mathrm{~h} \mathrm{FBE}$ ), whereas during the post-fumigation period, Pro values remained lower than those at time 0 (Figures $5 \mathbf{B}$ and Supplementary Table S2). Conversely, in $\mathrm{WS}+\mathrm{O}_{3}$ plants, Pro content peaked after $1 \mathrm{~h} \mathrm{FBE}(+96 \%$, in comparison to controls), then declined at $2 \mathrm{~h}$ FBE (at the same concentrations shown before the beginning of $\mathrm{O}_{3}$-exposure), increased again at $5 \mathrm{~h} \mathrm{FBE}$ $(+69 \%)$ and reaching a maximum at $8 \mathrm{~h} \mathrm{FBE}$, with the maximum values (sixfold higher than at time 0 ). Finally, Pro concentration of $\mathrm{WS}+\mathrm{O}_{3}$ leaves decreased at $24 \mathrm{~h} \mathrm{FBE}$, although they remained higher than before the $\mathrm{O}_{3}$-exposure (more than two fold).

\section{DISCUSSION}

In this study, the behavior of the Mediterranean evergreen Q. ilex subjected or not to drought, and later exposed to an acute $\mathrm{O}_{3}$ exposure, was evaluated in terms of cross-talk responses among signaling molecules. The aim was to confirm or disentangle the hypothesis according to which drought stress influences the responses of plants to acute episodes of $\mathrm{O}_{3}$ exposure.

\section{Physiological and Biochemical Responses to Drought}

Although drought induced a strong decrease in $\mathrm{PD} \Psi_{\mathrm{W}}$ (reaching lower values than those reported in a previous study; Cotrozzi

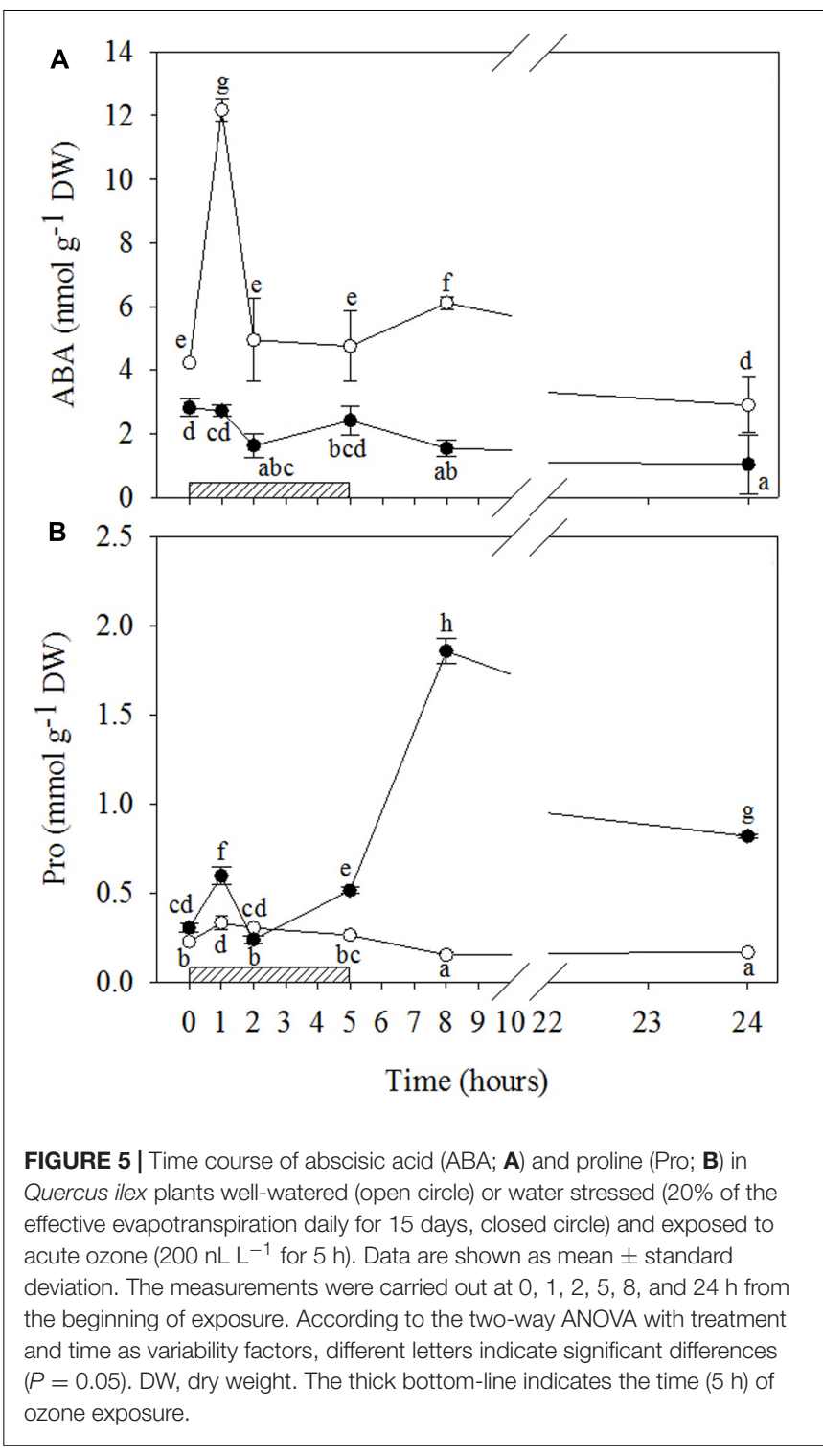

et al. (2016b), attributable to different growing seasons between experiments), the RWC of WS leaves did not significantly change in comparison to the WW leaves. This indicates that a good level of leaf hydration was also maintained under drought conditions, RWC being a reliable indicator of leaf water content (Rosales-Serna et al., 2004). This result is in accordance with the accumulation of Pro, a metabolite that is considered an important compatible solute which (i) facilitates water absorption by increasing the cell osmotic potential (Ashraf and Foolad, 2007), and (ii) reduces cell damage (Filippou et al., 2014). The important role of Pro in response to water stress has already been reported in this species where Pro played a key role in the high plasticity of $Q$. ilex under a long period of moderate water stress (Cotrozzi et al., 2016b).

In WS plants, the strong decline in $\mathrm{CO}_{2}$ photo-assimilation was attributable to coordinated and concomitant stomatal and mesophyll limitations, which is in line the results obtained by 
several authors (e.g., Centritto et al., 2009; Flexas et al., 2013). The drop in A levels was higher than that in $g_{s}$, thus leading to lower values of intrinsic water use efficiency (data not shown), as already reported in this species when subjected to water stress (Cotrozzi et al., 2016b).

These outcomes indicate that $\mathrm{CO}_{2}$ assimilation was strongly influenced not only by stomatal behavior but also by mesophyll limitations, as demonstrated by the increase in $\mathrm{C}_{\mathrm{i}}$. Drought compromised the PSII photochemical efficiency in light adapted leaves with decreases in $\Phi_{\mathrm{PSII}}$ and $\mathrm{qP}$ levels, although this inhibition did not determine PSII photoinhibition, as confirmed by unchanged values in the $\mathrm{F}_{\mathrm{v}} / \mathrm{F}_{m}$ ratio. In WS conditions, the lower $\mathrm{CO}_{2}$ assimilation rate induced, in turn, a reduced consumption of ATP and NADPH synthesized into the chloroplasts and, consequently, led to an excess of excitation energy in the thylakoid membrane, which was only partially dissipated, via non-photochemical mechanisms (increase in qNP). The remaining excess of reducing power in WS plants altered the ROS levels (although $\mathrm{H}_{2} \mathrm{O}_{2}$ did not change, a strong increase of $\mathrm{O}_{2}{ }^{-}$was observed). This led to a modification in phytohormones and other signaling molecule cross-talk in terms of (i) promoting oxidative stress and (ii) modulating leaf senescence (Munné-Bosch and Alegre, 2004; Miller et al., 2010; Baxter et al., 2014), which is a defense commonly activated in response to both a plethora of abiotic and biotic stresses (Wingler and Roitsch, 2008).

Among phytohormones, the important roles of ABA and ET in plant responses to drought is well known (Munné-Bosch and Alegre, 2004) as ABA represents the most important regulator of stomata functioning (Wilkinson and Davies, 2002), whereas ET is a shoot growth inhibitor and a promoter of ripening, senescence and abscission (Abeles et al., 1992). However, ET can inhibit ABA-induced stomatal closure (Tanaka et al., 2005). Wilkinson and Davies $(2009,2010)$ reported that under stressoxidative conditions, an ET-antagonism of the stomatal response to ABA occurs. This interaction was confirmed by our data (ABA decreased, while ET increased), suggesting that drought-induced ET biosynthesis could be considered a marker of leaf senescence (Dangl et al., 2000; Dolferus, 2014).

In addition, SA and JA have been shown to play a central role in leaf senescence (Abreu and Munné-Bosch, 2008), although they are well known for triggering defense reactions against biotrophic and necrotrophic pathogens such as induced resistance (Barna et al., 2012; Shigenaga and Argueso, 2016). In particular, SA and JA interact at physiological levels in many growth and developmental processes, and they play a role in controlling gene expression during leaf senescence (Abreu and Munné-Bosch, 2008). However, as only the JA levels increased in WS leaves, it is reasonable that only JA participated in senescence-associated signaling and degradative processes of membranes. The significantly higher levels of JA shown by WS compared to WW plants indicate that lipid peroxidation producing substrates for octadecanoid pathways was exacerbated in limited water conditions. In particular, JA could be a promoter of leaf senescence in response to drought, thus leading to stomatal closure and accumulation of osmo-compatible solutes (in our case, only Pro), in line with Dar et al. (2015).

\section{Influence of Drought Stress on the Physiological and Biochemical Responses to $\mathrm{O}_{3}$ Exposure}

The physiological responses observed in $\mathrm{O}_{3}$-stressed plants were similar to those shown at the end of water deprivation, and in accordance with a previous study by our research group on Q. ilex exposed to $\mathrm{O}_{3}$ (Cotrozzi et al., 2016b). At the end of the fumigation, the $\mathrm{O}_{3}$-induced stomatal closure found in both $\mathrm{WW}+\mathrm{O}_{3}$ and $\mathrm{WS}+\mathrm{O}_{3}$ leaves led to significant reductions in $\mathrm{CO}_{2}$ assimilation. The more pronounced decrease in $\mathrm{A}$ in $\mathrm{WW}+\mathrm{O}_{3}$ compared to WS $+\mathrm{O}_{3}$ leaves, as well as the lack of a further decrease in $\mathrm{A}$ observed in $\mathrm{WS}+\mathrm{O}_{3}$ plants throughout the recovery phase, was probably attributable to the very low $\mathrm{CO}_{2}$ assimilation rate shown by water stressed plants before the beginning of the fumigation. The increase in $\mathrm{C}_{\mathrm{i}}$ level in plants exposed to $\mathrm{O}_{3}$ indicates that the pollutant gas influenced not only stomatal conductance but, as with after water stress, also the mesophyll activity. In fact, an impairment of PSII activity was recorded. Although $F_{\mathrm{V}} / F_{m}$ and $\Phi_{\mathrm{PSII}}$ values decreased significantly after $\mathrm{O}_{3}$ exposure in both $\mathrm{WW}+\mathrm{O}_{3}$ and $\mathrm{WS}+\mathrm{O}_{3}$ plants, the reduction was more pronounced in $\mathrm{WS}+\mathrm{O}_{3}$ plants. This behavior was linked to different quenching responses to the leaf-water status of plants. In $\mathrm{WW}+\mathrm{O}_{3}$ plants, where $\mathrm{qP}$ did not decrease, a mechanism aimed at dissipating the excess excitation energy was activated (qNP increased). By contrast, in WS $+\mathrm{O}_{3}$ leaves, the $\mathrm{O}_{3}$-induced decrease in $\mathrm{qP}$ was ascribable to the fact that qNP values were already high (probably at their maximum in relation to the capability of plants to activate this mechanism) after drought, and the leaves were not able to enhance this type of dissipation mechanism. The complete recovery of PSII photochemical activity during the recovery time after drought and $\mathrm{O}_{3}$ exposure indicates that the decrease in PSII activity was sufficient to prevent the photosynthetic apparatus from undergoing irreversible damage.

Unlike the ecophysiological measurements, microscopic analyses highlighted significant differences between plants exposed $\left(\mathrm{WW}+\mathrm{O}_{3}, \mathrm{WS}+\mathrm{O}_{3}\right)$ or not (WW and WS) to the gaseous pollutant. Although visible symptoms were not shown by any of the plants irrespectively of the applied treatment, $\mathrm{DAB}$ staining and Evan's blue incorporation observed in $\mathrm{WW}+\mathrm{O}_{3}$ and WS $+\mathrm{O}_{3}$ leaves $5 \mathrm{~h}$ FBE indicated that $\mathrm{H}_{2} \mathrm{O}_{2}$ deposition and cell death had already occurred at the end of exposure. This confirms that $\mathrm{O}_{3}$ resembles the HR occurring in incompatible plant-pathogen interactions (Iriti and Faoro, 2008; Vainonen and Kangasjärvi, 2015). An integrated perspective has been proposed to explain how phytohormones and signaling molecules might be involved in molecular events (namely lesion initiation, propagation, and containment) leading to $\mathrm{O}_{3}$-induced HR-mimicking foliar symptoms (Overmeyer et al., 2003, 2005; Kangasjärvi et al., 2005). ROS, phytohormones and other signaling molecules have a pivotal role in both HR-mimicking responses induced by acute $\mathrm{O}_{3}$ and in promoting leaf senescence under drought (as shown by WS plants). The trends of these molecules were monitored in both well-watered and droughtstressed plants during and after $\mathrm{O}_{3}$ exposure, in order to test the hypotheses of this work. 
Given that $\mathrm{O}_{3}$ induces an endogenous, active and selfpropagating ROS generation in the apoplast and a subsequent cellular oxidative burst, some authors have proposed that shortterm $\mathrm{O}_{3}$ exposure mimics pathogen infection (Rao et al., 2000; Kangasjärvi et al., 2005; Carmody et al., 2016). The two $\mathrm{O}_{3}$-induced $\mathrm{H}_{2} \mathrm{O}_{2}$ peaks observed in our saplings, irrespectively of the water conditions, are analogous to the biphasic response usually observed during the establishment of the HR of plants against pathogens. The first $\mathrm{H}_{2} \mathrm{O}_{2}$ peak usually reflects elicitation by pathogen-associated molecular patterns, and the second reflects the interaction between a pathogen-encoded virulence gene product with a plant resistance gene (Mur et al., 2009). In our study, the first peak observed during the fumigation was attributable to $\mathrm{O}_{3}$-decomposition, whereas the second peak, in the recovery period, could be entirely ascribable to the plant metabolism, in line with Mahalingam et al. (2006), Di Baccio et al. (2012), and Pellegrini et al. (2013) in herbaceous species.

Although the similarity in $\mathrm{H}_{2} \mathrm{O}_{2}$ profiles over time between $\mathrm{WW}+\mathrm{O}_{3}$ and $\mathrm{WS}+\mathrm{O}_{3}$ conditions, the divergence in the magnitude of their relative peaks (the second peak of the $\mathrm{WW}+\mathrm{O}_{3}$ plants was much greater than their first peak and greater than the second peak of the $\mathrm{WS}+\mathrm{O}_{3}$ plants, where the two peaks were not significantly different from each other) suggests that drought partially inhibited the response to $\mathrm{O}_{3}$-stress. As $\mathrm{H}_{2} \mathrm{O}_{2}$ is one of the most important products of oxidative stress (Gill and Tuteja, 2010), it is reasonable to speculate that the biphasic trend of $\mathrm{H}_{2} \mathrm{O}_{2}$ observed in $Q$. ilex, irrespectively of drought stress, might reflect the biphasic oxidative burst in response to $\mathrm{O}_{3}$, in line with several authors (e.g., Wohlgemuth et al., 2002; Di Baccio et al., 2012).

However, this hypothesis is strengthened by $\mathrm{O}_{2}{ }^{-}$only in $\mathrm{WW}+\mathrm{O}_{3}$ plants, where a biphasic time course of $\mathrm{O}_{2}{ }^{-}$levels was shown concurrently with $\mathrm{H}_{2} \mathrm{O}_{2}$. Kangasjärvi et al. (2005) reported similar temporal changes in $\mathrm{ROS}$ for $\mathrm{O}_{3}$-sensitive genotypes of several species (e.g., tobacco, tomato, birch), whereas only a modest increase in the first hours of exposure was observed in $\mathrm{O}_{3}$-tolerant genotypes. Conversely, the different $\mathrm{O}_{2}{ }^{-}$ patterns of the $\mathrm{WS}+\mathrm{O}_{3}$ plants suggest a possible dual function of this radical depending on water stress. In fact, the significant decrease in $\mathrm{O}_{2}{ }^{-}$observed in $\mathrm{WS}+\mathrm{O}_{3}$ plants during the first hours of exposure suggests that under drought $+\mathrm{O}_{3}$ superoxide anion may act as a precursor of $\mathrm{H}_{2} \mathrm{O}_{2}$ and even more toxic radical derivatives. However, the accumulation of $\mathrm{O}_{2}{ }^{-}$had already been induced by drought before the beginning of $\mathrm{O}_{3}$-exposure. On the other hand, the marked increase in $\mathrm{O}_{2}{ }^{-}$content at the end of the exposure demonstrates that this radical may also be directly involved in the $\mathrm{O}_{3}$-oxidative burst.

Reactive oxygen species should not be considered as exclusively deleterious and harmful. They can (i) play a key role in intracellular communication which triggers the acclimation ability, and (ii) indirectly orchestrate PCD (Mittler et al., 2011; Xia et al., 2015; Carmody et al., 2016). The amplification of ROS signals and the complete induction of defense genes seem to require signal molecules (Overmeyer et al., 2003). The differences observed in the present study in $\mathrm{O}_{3}$-induced ROS extent dynamics in relation to water stress suggest a rather complex network of events in signal transduction, involving other molecules (e.g., phytohormones) and processes. Metabolites such as ET, ABA, SA and JA may interact at the physiological level in many growth and developmental processes, with a key role in controlling gene expression during leaf senescence. Most of the genes regulated by these metabolites are defense-related (Fossdal et al., 2007), participating therefore in responses to $\mathrm{O}_{3}$ (Xu et al., 2015).

Under both biotic and abiotic stresses, SA is required for the induction of PCD, controlling and potentiating the oxidative burst together with ET, whereas JA is involved in limiting the spread of lesions (van Loon et al., 2006; Shigenaga and Argueso, 2016). There are three phases that highlight the influence of ABA on stress conditions (Rejeb I.B. et al., 2014). First, ABA induces stomatal closure, which leads to a reduction in water loss (in this phase, SA, JA and ET may not yet be activated and ABA can antagonize their induction). In the second step, there is a postinfection reaction- an intact ABA signaling pathway is required to increase callose accumulation in affected plants, and the presence of ABA can induce or repress additional callose accumulation depending on the environmental conditions. The third phase begins when pathogen-associated molecular patterns stimulate the accumulation of specific SA, JA, and ET hormones in order to regulate the defense reaction.

In our study, the patterns of phytohormones during and after $\mathrm{O}_{3}$ treatment were completely different in $\mathrm{WW}+\mathrm{O}_{3}$ and $\mathrm{WS}+\mathrm{O}_{3}$ plants, showing how drought stress has a pivotal role in $\mathrm{O}_{3}$ responses, and how these signal molecules may be altered in relation to water stress. The ET and ABA accumulations observed throughout the entire period of $\mathrm{O}_{3}$ exposure occurred only in well-watered conditions. On the other hand, when plants had been previously subjected to water stress, their unchanged values suggest that ET and ABA were not involved in either signalingresponses to $\mathrm{O}_{3}$, or senescence strategies (as shown for WS plants).

It is worth noting that (i) the maximal ET emission in $\mathrm{WW}+\mathrm{O}_{3}$ plants coincided with the second peak of $\mathrm{H}_{2} \mathrm{O}_{2}$ and $\mathrm{O}_{2}{ }^{-}$; (ii) the first peak of $\mathrm{ABA}$ (during $\mathrm{O}_{3}$ treatment) preceded that of $\mathrm{H}_{2} \mathrm{O}_{2}$, suggesting that ABA could act as a stress messenger by inducing $\mathrm{H}_{2} \mathrm{O}_{2}$ (Jiang and Zhang, 2002) and consequently stomatal closure (as confirmed by the decrease in $\mathrm{g}_{\mathrm{s}}$ values observed at the end of exposure), and (iii) the weaker second ABA peak (in the recovery phase) was concomitant with the maximum $\mathrm{H}_{2} \mathrm{O}_{2}$ and $\mathrm{O}_{2}{ }^{-}$levels and the maximal ET emission. These outcomes confirm a spatial and functional correlation between ROS and the accumulation of these phytohormones.

The SA induction observed, irrespectively of whether the plants had been subjected to drought or not, suggests that this metabolite is also an important modulator of $\mathrm{O}_{3}$-induced responses (Pasqualini et al., 2002; Horváth et al., 2007). However, the differences between $\mathrm{WW}+\mathrm{O}_{3}$ and $\mathrm{WS}+\mathrm{O}_{3}$ plants show that the functioning of $\mathrm{SA}$ is dependent on water stress. In $\mathrm{WW}+\mathrm{O}_{3}$ conditions, the strong increase in SA during the first hours of the treatment and at the end of the $\mathrm{O}_{3}$ fumigation, confirms the central role of this metabolite in lesion initiation and progression in response to $\mathrm{O}_{3}$ (Tamaoki, 2008). In addition, the greater SA concentration corresponded with the maximal ABA stimulation and the first increase in ET, thus demonstrating the 
synergistic action of these hormones in the regulation of defense reactions (Roychoudhury et al., 2013; Wang et al., 2013). By contrast, the biphasic time course of SA (similar to that of $\mathrm{H}_{2} \mathrm{O}_{2}$ ) shown by $\mathrm{WS}+\mathrm{O}_{3}$ plants (although slight) recalls the biphasic induction that develops during biotrophic pathogen infection (Mur et al., 2009). Here, the similarity in magnitude of the two SA peaks suggests that the first accumulation of this metabolite (concomitant with the first peak of $\mathrm{H}_{2} \mathrm{O}_{2}$ ) did not actuate the second increase in $\mathrm{H}_{2} \mathrm{O}_{2}$ and hence did not affect the level of plant defense.

The highest concentration of JA observed in $\mathrm{WW}+\mathrm{O}_{3}$ plants during the first hour of fumigation coincided with the initial increase in ET and the maximum accumulation of SA and $\mathrm{ABA}$, thus also demonstrating a spatial and functional correlation between these compounds (Thaler et al., 2012). The significant $\mathrm{O}_{3}$-induced decrease in JA levels observed in $\mathrm{WS}+\mathrm{O}_{3}$ plants during and after the exposure suggests that JA did not promote leaf senescence in $\mathrm{O}_{3}$-treated leaves in spite of the high concentrations of this metabolite observed in $\mathrm{WS}+\mathrm{O}_{3}$ plants, not excluding the involvement of JA in senescence-associated signaling (Abreu and Munné-Bosch, 2008). In fact, the JA level in $\mathrm{WS}+\mathrm{O}_{3}$ plants increased again after the end of fumigation, reaching higher values than those found in the $\mathrm{WW}+\mathrm{O}_{3}$ counterpart during the recovery. JA is known to rapidly inhibit the expression of genes involved in photosynthesis by inducing chlorophyll loss and cellular changes that cause less photochemical damage (Santino et al., 2013).

Proline plays several roles in plant responses to abiotic and biotic stresses, and under stress its metabolism is affected by multiple and complex regulatory pathways which can profoundly influence cell death and survival in plants (Zhang and Becker, 2015). The slight increase in Pro observed in WS plants compared to WW likely indicates its role as an osmoprotectant. By the same token the $\mathrm{O}_{3}$-induced increase in Pro observed in $\mathrm{WW}+\mathrm{O}_{3}$ plants only during the first hours of treatment and coinciding with the maximal $\mathrm{ABA}, \mathrm{SA}$ and JA stimulation and the first increase in ET, $\mathrm{H}_{2} \mathrm{O}_{2}$ and $\mathrm{O}_{2}{ }^{-}$, suggests a potential cross-talk among signaling molecules in regulating Pro metabolism, as

\section{REFERENCES}

Abeles, F. B., Morgan, P. W., and Saltveit, M. E. Jr. (1992). Ethylene in Plant Biology. San Diego, CA: Academic Press.

Abreu, M. E., and Munné-Bosch, S. (2008). Salicylic acid may be involved in the regulation of drought-induced leaf senescence in perennials: a case study in field-grown Salvia officinalis L. plants. Environ. Exp. Bot. 64, 105-112. doi: 10.1016/j.envexpbot.2007.12.016

Alonso, R., Elvira, S., Gonzalez-Fernandez, I., Calvete, H., Garcia-Gomez, H., and Bermejo, V. (2014). Drought stress does not protect Quercus ilex L. from ozone effects: results from a comparative study of two subspecies differing in ozone sensitivity. Plant Biol. 16, 375-384. doi: 10.1111/plb. 12073

Apel, K., and Hirt, H. (2004). Reactive oxygen species: metabolism, oxidative stress, and signal transduction. Annu. Rev. Plant Biol. 55, 373-399. doi: 10.1146/ annurev.arplant.55.031903.141701

Ashraf, M., and Foolad, M. R. (2007). Roles of glycine betaine and proline in improving plant abiotic stress resistance. Environ. Exp. Bot. 59, 206-216. doi: 10.1016/j.envexpbot.2005.12.006 previously reported by Rejeb K.B et al. (2014). The role of Pro as an ROS scavenger has also been reported (Szabados and Savouré, 2009; Banu et al., 2010; Zhang and Becker, 2015). In $\mathrm{WW}+\mathrm{O}_{3}$ plants the lack of accumulation in Pro at $8 \mathrm{~h} \mathrm{FBE}$ was concurrent with a strong increase in $\mathrm{H}_{2} \mathrm{O}_{2}$, whereas in $\mathrm{WS}+\mathrm{O}_{3}$ the huge increase in Pro at $8 \mathrm{~h}$ FBE suppressed the increase in $\mathrm{H}_{2} \mathrm{O}_{2}$ (which remained at the same levels shown at $1 \mathrm{~h} \mathrm{FBE}$ ), thus suggesting an $\mathrm{H}_{2} \mathrm{O}_{2}$-scavenging role in these water conditions. This mechanism was also confirmed at $24 \mathrm{~h}$ FBE. Several studies have attributed an antioxidant feature to Pro, suggesting the capability of Pro in $\mathrm{O}_{2}{ }^{-}$and $\mathrm{H}_{2} \mathrm{O}_{2}$ quenching (e.g., Szabados and Savouré, 2009; Wang et al., 2009).

\section{AUTHOR CONTRIBUTIONS}

The work presented here was carried out in collaboration among all authors. GL and RM defined the research theme and obtained funding. LC, DR, EP, MT, AT, and ML designed methods, carried out laboratory experiments and analyzed the data. LG, CN, and PV co-designed experiments, discussed analyses, interpreted the results, and wrote the paper. All authors have contributed to, seen and approved the manuscript.

\section{ACKNOWLEDGMENTS}

This study was supported by MIUR, Rome, project PRIN 2010-2011 "Planning the green city in the global change era: urban tree functions and suitability for predicted future climates (TreeCity)". The authors are grateful to Mr Andrea Bianchi and Ms Romina Papini for technical support.

\section{SUPPLEMENTARY MATERIAL}

The Supplementary Material for this article can be found online at: http://journal.frontiersin.org/article/10.3389/fpls.2017.01020/ full\#supplementary-material

Banu, N. A., Hoque, A., Watanabe-Sugimoto, M., Islam, M. M., Uraji, M., Matsuoka, K., et al. (2010). Proline and glycinebetaine ameliorated $\mathrm{NaCl}$ stress via scavenging of hydrogen peroxide and methylglyoxal but not superoxide or nitric oxide in tobacco cultured cells. Biosci. Biotechnol. Biochem. 74, 2043-2049. doi: 10.1271/bbb.100334

Barna, B., Fodor, J., Harrach, B. D., Pogány, M., and Király, Z. (2012). The Janus face of reactive oxygen species in resistance and susceptibility of plants to necrotrophic and biotrophic pathogens. Plant Physiol. Biochem. 59, 37-43. doi: 10.1016/j.plaphy.2012.01.014

Bates, B. C., Kundzewicz, Z. W., Wu, S., and Palutikof, J. P. (2008). Climate Change and Water. Technical Paper of the Intergovernmental Panel on Climate Change. Geneva: IPCC Secretariat.

Baxter, A., Mittler, R., and Suzuki, N. (2014). ROS as key players in plant stress signalling. J. Exp. Bot. 65, 1229-1240. doi: 10.1093/jxb/ert375

Bussotti, F., Bettini, D., Grossoni, P., Mansuino, S., Nibbi, R., Soda, C., et al. (2002). Structural and functional traits of Quercus ilex in response to water availability. Environ. Exp. Bot. 47, 11-23. doi: 10.1016/S0098-8472(01)00111-3

Calatayud, V., Cerveró, J., Calvo, E., García-Brejio, F. J., Reig-Armiñana, J., and Sanz, M. J. (2011). Responses of evergreen and deciduous Quercus species to 
enhanced ozone levels. Environ. Pollut. 159, 55-63. doi: 10.1016/j.envpol.2010. 09.024

Calderòn Guerrero, C. C., Günthardt-Goerg, M. S., and Vollenweider, P. (2013). Foliar symptoms triggered by ozone stress in irrigated holm oaks from the city of Madrid, Spain. PLoS ONE 8:e69171. doi: 10.1371/journal.pone.0069171

Carmody, M., Waszczak, C., Idänheimo, N., Saarinen, T., and Kangasjärvi, J. (2016). ROS signaling in a destabilized world: a molecular understanding of climate change. J. Plant Physiol. 203, 69-83. doi: 10.1016/j.jplph.2016. 06.008

Centritto, M., Lauteri, M., Monteverdi, M. C., and Serraj, R. (2009). Leaf gas exchange, carbon isotope discrimination, and grain yield in contrasting rice genotypes subjected to water deficits during the reproductive stage. J. Exp. Bot. 60, 2325-2339. doi: 10.1093/jxb/erp123

Claeys, H., and Inzé, D. (2013). The agony of choice: how plants balance growth and survival under water-limiting conditions. Plant Physiol. 162, 1768-1779. doi: $10.1104 /$ pp.113.220921

Cotrozzi, L., Campanella, A., Pellegrini, E., Lorenzini, G., Nali, C., and Paoletti, E. (2016a). Phenylpropanoids are key players in the antioxidant defense to ozone of European ash, Fraxinus excelsior. Environ. Sci. Pollut. Res. doi: 10.1007/ s11356-016-8194-8 [Epub ahead of print].

Cotrozzi, L., Remorini, D., Pellegrini, E., Landi, M., Massai, R., Nali, C., et al. (2016b). Variations in physiological and biochemical traits of oak seedlings grown under drought and ozone stress. Physiol. Plant. 157, 69-84. doi: 10.1111/ ppl.12402

Dangl, J., Dietrich, R., and Thomas, H. (2000). "Senescence and programmed cell death," in Biochemistry and Molecular Biology of Plants, eds B. Buchanan, W. Gruissemand, and R. Jones (Rochville, MD: American Society of Plant Physiologists), 1044-1100.

Dar, T. A., Uddin, M., Khan, M. M. A., Hakeem, K. R., and Jaleel, H. (2015). Jasmonates counter plant stress: a review. Environ. Exp. Bot. 115, 49-57. doi: 10.1016/j.envexpbot.2015.02.010

Di Baccio, D., Ederli, L., Marabottini, R., Badiani, M., Francini, A., Nali, C., et al. (2012). Similar foliar lesions but opposite hormonal patterns in a tomato mutant impaired in ethylene perception and its near isogenic wild type challenged with ozone. Environ. Exp. Bot. 75, 286-297. doi: 10.1016/j. envexpbot.2011.08.001

Dolferus, R. (2014). To grow or not to grow: a stressful decision for plants. Plant Sci. 229, 247-261. doi: 10.1016/j.plantsci.2014.10.002

Filippou, P., Bouchagier, P., Skotti, E., and Fotopoulos, V. (2014). Proline and reactive oxygen/nitrogen species biosynthesis is involved in the tolerant response of the invasive plant species Ailanthus altissima to drought and salinity. Environ. Exp. Bot. 97, 1-10. doi: 10.1016/j.envexpbot.2013.09.010

Flexas, J., Niinemets, Ü, Gallé, A., Barbour, M. M., Centritto, M., Diaz-Espejo, A., et al. (2013). Diffusional conductances to $\mathrm{CO}_{2}$ as a target for increasing photosynthesis and photosynthetic water-use efficiency. Photosynth. Res. 117, 45-59. doi: 10.1007/s11120-013-9844-Z

Fossdal, C. G., Nagy, N. E., Johnsen, Ø, and Dalen, L. S. (2007). Local and systemic stress responses in Norway spruce: similarities in gene expression between a compatible pathogen interaction and drought stress. Physiol. Mol. Plant Pathol. 70, 161-173. doi: 10.1016/j.pmpp.2007.09.002

Genty, B., Briantais, J. M., and Baker, N. R. (1989). The relationship between the quantum yield of photosynthetic electron transport and quenching of chlorophyll fluorescence. Biochim. Biophys. Acta 990, 87-92. doi: 10.1016/ S0304-4165(89)80016-9

Gill, S. S., and Tuteja, N. (2010). Reactive oxygen species and antioxidant machinery in abiotic stress tolerance in crop plants. Plant Physiol. Biochem. 48, 909-930. doi: 10.1016/j.plaphy.2010.08.016

Gimeno, T. E., Pías, B., Lemos-Filho, P., and Valladares, F. (2008). Plasticity and stress tolerance override local adaptation in the responses of Mediterranean holm oak seedlings to drought and cold. Tree Physiol. 29, 87-98. doi: 10.1093/ treephys/tpn007

Gray, S. B., and Brady, S. M. (2016). Plant developmental responses to climate change. Dev. Biol. 419, 64-77. doi: 10.1016/j.ydbio.2016.07.023

Guidi, L., Remorini, D., Cotrozzi, L., Giordani, T., Lorenzini, G., Massai, R., et al. (2017). The harsh life of an urban tree: the effect of a single pulse of ozone in salt-stressed Quercus ilex saplings. Tree Physiol. 37, 246-260. doi: 10.1093/ treephys/tpw103
Horváth, E., Szalai, G., and Janda, T. (2007). Induction of abiotic stress tolerance by salicylic acid signaling. J. Plant Growth Regul. 26, 290-300. doi: 10.1007/s00344007-9017-4

Iriti, M., and Faoro, F. (2008). Chemical diversity and defence metabolism: how plants cope with pathogens and ozone pollution. Int. J. Mol. Sci. 10, 3371-3399. doi: 10.3390/ijms10083371

Iyer, N. J., Tang, Y., and Mahalingam, R. (2013). Physiological, biochemical and molecular responses to a combination of drought and ozone in Medicago truncatula. Plant Cell Environ. 36, 706-720. doi: 10.1111/pce.12008

Jiang, M., and Zhang, J. (2002). Water stress-induced abscisic acid accumulation triggers the increased generation of reactive oxygen species and up-regulates the activities of antioxidant enzymes in maize leaves. J. Exp. Bot. 53, 2401-2410. doi: 10.1093/jxb/erf090

Kangasjärvi, J., Jaspers, P., and Kollist, H. (2005). Signalling and cell death in ozoneexposed plants. Plant Cell Environ. 28, 1021-1036. doi: 10.1111/j.1365-3040. 2005.01325.x

Kangasjärvi, J., Talvinen, J., Utriainen, M., and Karjalainen, R. (1994). Plant defence systems induced by ozone. Plant Cell Environ. 17, 783-794. doi: 10.1111/j.13653040.1994.tb00173.x

Kock, J. R., Creelman, R. A., Eshita, S. M., Seskar, M., Mullet, J. E., and Davis, K. R. (2000). Ozone sensitivity in hybrid poplar correlates with insensitivity to both salycilic acid and jasmonic acid. The role of programmed cell death in lesion formation. Plant Physiol. 123, 487-496. doi: 10.1104/pp.123.2.487

Kurz, C., Schmieden, U., Strobel, P., and Wild, A. (1998). The combined effect of $\mathrm{CO}_{2}$, ozone and drought on the radical scavenging system of young oak trees (Quercus petraea) - a phytothron study. Chemosphere 36, 783-788. doi: 10.1016/S0045-6535(97)10124-2

Langebartels, C., Schraudner, M., Heller, W., Ernst, D., and Sandermann, H. (2002). "Oxidative stress and defense reactions in plants exposed to air pollutants and UV-B radiation," in Oxidative Stress in Plants, eds D. Inzé and M. Van Montagu (London: Taylor \& Francis), 105-135.

Lorenzini, G., Medeghini Bonatti, P., Nali, C., and Baroni Fornasiero, R. (1994). The protective effect of rust infection against ozone, sulphur dioxide and paraquat toxicity symptoms in broad bean. Physiol. Mol. Plant Pathol. 45, 263-279. doi: 10.1016/S0885-5765(05)80058-X

Mahalingam, R., Jambunathan, N., Gunjan, S. K., Faustin, E., Weng, H., and Ayoubi, P. (2006). Analysis of oxidative signalling induced by ozone in Arabidopsis thaliana. Plant Cell Environ. 29, 1357-1371. doi: 10.1111/j.13653040.2006.01516.x

Matesanz, S., and Valladares, F. (2014). Ecological and evolutionary responses of Mediterranean plants to global change. Environ. Exp. Bot. 103, 53-67. doi: 10.1016/j.envexpbot.2013.09.004

Miller, G., Suzuki, N., Ciftci-Yilmaz, S., and Mittler, R. (2010). Reactive oxygen species homeostasis and signalling during drought and salinity stresses. Plant Cell Environ. 33, 453-467. doi: 10.1111/j.1365-3040.2009.02041.x

Mittler, R., Vanderauwera, S., Suzuki, N., Miller, G., Tognetti, V. B., Vandepele, K., et al. (2011). ROS signaling: the new wave? Trends Plant Sci. 16, 1360-1385. doi: 10.1016/j.tplants.2011.03.007

Munné-Bosch, S., and Alegre, L. (2004). Die and let live: leaf senescence contributes to plant survival under drought stress. Funct. Plant Biol. 31, 203-213. doi: 10.1071/FP03236

Mur, L. A. J., Lloyd, A. J., Cristesce, S. M., Harren, F. J. M., Hall, M. A., and Smith, A. R. (2009). Biphasic ethylene production during the hypersensitive response in Arabidopsis. Plant Signal. Behav. 4, 610-613. doi: 10.4161/psb.4.7.8904

Noctor, G., Mhamdi, A., and Foyer, C. H. (2014). The roles of reactive oxygen metabolism in drought: not so cut and dried. Plant Physiol. 164, 1636-1648. doi: $10.1104 /$ pp.113.233478

Overmeyer, K., Brosche, M., and Kangasjärvi, J. (2003). Reactive oxygen species and hormonal control of cell death. Trends Plant Sci. 8, 335-342. doi: 10.1016/ S1360-1385(03)00135-3

Overmeyer, K., Brosché, M., Pellinen, R., Kuittinen, T., Tuominen, H., Ahlfors, R., et al. (2005). Ozone-induced programmed cell death in the Arabidopsis radicalinduced cell death1 mutant. Plant Physiol. 137, 1092-1104. doi: 10.1104/pp.104. 055681

Panek, J. A., Kurpius, M. R., and Goldstein, A. H. (2002). An evaluation of ozone exposure metrics for a seasonally drought-stressed ponderosa pine ecosystem. Environ. Pollut. 117, 93-100. doi: 10.1016/S0269-7491(01)00155-5 
Pasqualini, S., Della Torre, G., Ferranti, F., Ederli, L., Piccioni, C., Reale, L., et al. (2002). Salicylic acid modulates ozone-induced hypersensitive cell death in tobacco plants. Physiol. Plant. 115, 204-212. doi: 10.1034/j.1399-3054.2002. 1150205.x

Pellegrini, E., Trivellini, A., Campanella, A., Francini, A., Lorenzini, G., Nali, C., et al. (2013). Signaling molecules and cell death in Melissa offcinalis plants exposed to ozone. Plant Cell Rep. 32, 1965-1980. doi: 10.1007/s00299-0131508-0

Pellegrini, E., Trivellini, A., Cotrozzi, L., Vernieri, P., and Nali, C. (2016). "Involvement of phytohormones in plant responses to ozone," in Plants Hormones Under Challenging Environmental Factors, eds G. J. Ahammed and J.-Q. Yu (Dordrrecht: Springer), 215-245. doi: 10.1007/978-94-017-7758-2_9

Pollastrini, M., Desotgiu, R., Camin, F., Ziller, L., Gerosa, G., Marzuoli, R., et al. (2014). Severe drought events increase the sensitivity to ozone on poplar clones. Environ. Exp. Bot. 100, 94-104. doi: 10.1016/j.envexpbot.2013. 12.016

Ramegowda, V., and Senthil-Kumar, M. (2015). The interactive effects of simultaneous biotic and abiotic stresses on plants: mechanistic understanding from drought and pathogen combination. J. Plant Physiol. 176, 47-54. doi: 10.1016/j.jplph.2014.11.008

Rao, M. V., and Davis, K. R. (2001). The physiology of ozone and induced cell death. Planta 213, 682-690. doi: 10.1007/s004250100618

Rao, M. V., Koch, J. R., and Davis, K. R. (2000). Ozone: a tool for probing programmed cell death in plants. Plant Mol. Biol. 44, 345-358. doi: 10.1007/ 978-94-010-0934-8-8

Rejeb, I. B., Pastor, V., and Mauch-Mani, B. (2014). Plant responses to simultaneous biotic and abiotic stress: molecular mechanisms. Plants 3, 458-475. doi: 10. 3390/plants3040458

Rejeb, K. B., Abdelly, C., and Savouré, A. (2014). How reactive oxygen species and proline face stress together. Plant Physiol. Biochem. 80, 278-284. doi: 10.1016/j. plaphy.2014.04.007

Rosales-Serna, R., Kohashi-Shibata, J., Acosta-Gallegos, J. A., Trejo-Lopez, C., Ortiz-Cereceres, J., and Kelly, J. D. (2004). Biomass distribution, maturity acceleration and yield in drought-stressed common bean cultivars. Field Crop Res. 85, 203-211. doi: 10.1016/S0378-4290(03)00161-8

Roychoudhury, A., Paul, S., and Basu, S. (2013). Cross-talk between abscisic aciddependent and abscisic acid-independent pathways during abiotic stress. Plant Cell Rep. 32, 985-1006. doi: 10.1007/s00299-013-1414-5

Santino, A., Taurino, M., De Domenico, S., Bonsegna, S., Poltronieri, P., Pastor, V., et al. (2013). Jasmonate signaling in plant development and defense response to multiple (a)biotic stresses. Plant Cell Rep. 32, 1085-1098. doi: 10.1007/s00299013-1441-2

Schreiber, U., Schliwa, U., and Bilger, W. (1986). Continuous recording of photochemical and non-photochemical chlorophyll fluorescence quenching with a new type of modulation fluorometer. Photosynth. Res. 20, 51-62. doi: 10.1007/BF00024185

Shigenaga, A. M., and Argueso, C. T. (2016). No hormone to rule them all: interactions of plant hormones during the responses of plants to pathogens. Semin. Cell Dev. Biol. 56, 174-189. doi: 10.1016/j.semcdb.2016.06.005

Smirnoff, N. (1993). The role of active oxygen in the response of plants to water deficit and desiccation. New Phytol. 125, 27-58. doi: 10.1111/j.1469-8137.1993. tb03863.x

Szabados, L., and Savouré, A. (2009). Proline: a multifunctional amino acid. Trends Plant Sci. 15, 89-97. doi: 10.1016/j.tplants.2009.11.009

Tamaoki, M. (2008). The role of phytohormone signaling in ozone-induced cell death in plants. Plant Signal. Behav. 3, 166-174. doi: 10.4161/psb.3.3.5538

Tanaka, Y., Sano, T., Tamaoki, M., Nakajima, N., Kondo, N., and Hasezawa, S. (2005). Ethylene inhibits abscisic acid-induced stomatal closure in Arabidopsis. Plant Physiol. 138, 2337-2343. doi: 10.1104/pp.105.063503

Thaler, J. S., Humphrey, P. T., and Whiteman, N. K. (2012). Evolution of jasmonate and salicylate signal crosstalk. Trends Plant Sci. 17, 260-270. doi: 10.1016/j. tplants.2012.02.010

Tonelli, M., Pellegrini, E., D’Angiolillo, F., Petersen, M., Nali, C., Pistelli, L., et al. (2015). Ozone-elicited secondary metabolites in shoot cultures of Melissa officinalis L. Plant Cell Tiss. Organ. Cult. 120, 617-629. doi: 10.1007/s11240014-0628-8

Trivellini, A., Ferrante, A., Vernieri, P., and Serra, G. (2011). Effects of abscisic acid on ethylene biosynthesis and perception in Hibiscus rosa-sinensis L. flower development. J. Exp. Bot. 15, 5437-5452. doi: 10.1093/jxb/err218

Vainonen, J. P., and Kangasjärvi, J. (2015). Plant signalling in acute ozone exposure. Plant Cell Environ. 38, 240-252. doi: 10.1111/pce.12273

van Loon, L. C., Geraats, B. P. J., and Linthorst, H. J. M. (2006). Ethylene as a modulator of disease resistance in plants. Trends Plant Sci. 11, 184-191. doi: 10.1016/j.tplants.2006.02.005

Vitale, M., Salvatori, E., Loreto, F., Fares, S., and Manes, F. (2008). Physiological responses of Quercus ilex leaves to water stress and acute ozone exposure under controlled conditions. Water Air Soil Pollut. 189, 113-125. doi: 10.1007/s11270007-9560-4

Vitti, A., Pellegrini, E., Nali, C., Lovelli, S., Sofo, A., Valerio, M., et al. (2016). Trichoderma harzianum T-22 induces systemic resistance in tomato infected by Cucumber mosaic virus. Front. Plant Sci. 7:1520. doi: 10.3389/fpls.2016.01520

Wang, F., Cui, X., Sun, Y., and Dong, C.-H. (2013). Ethylene signaling and regulation in plant growth and stress responses. Plant Cell Rep. 32, 1099-1109. doi: 10.1007/s00299-013-1421-6

Wang, F., Zeng, B., Sun, Z., and Zhu, C. (2009). Relationship between proline and $\mathrm{Hg} 21$-induced oxidative stress in a tolerant rice mutant. Arch. Environ. Contam. Toxicol. 56, 723-731. doi: 10.1007/s00244-008-9226-2

Wilkinson, S., and Davies, W. J. (2002). ABA-based chemical signaling: the co-ordination of responses to stress in plants. Plant Cell Environ. 25, 195-210. doi: 10.1046/j.0016-8025.2001.00824.x

Wilkinson, S., and Davies, W. J. (2009). Ozone suppresses soil drying- and abscisic acid (ABA)-induced stomatal closure via an ethylene-dependent mechanism. Plant Cell Environ. 32, 949-959. doi: 10.1111/j.1365-3040.2009.01970.x

Wilkinson, S., and Davies, W. J. (2010). Drought, ozone, ABA and ethylene: new insights from cell to plant to community. Plant Cell Environ. 33, 510-525. doi: 10.1111/j.1365-3040.2009.02052.x

Wingler, A., and Roitsch, T. (2008). Metabolic regulation of leaf senescence: interactions of sugar signaling with biotic and abiotic stress responses. Plant Biol. 10, 50-62. doi: 10.1111/j.1438-8677.2008.00086.x

Wohlgemuth, H., Mittelstrass, K., Kschieschan, S., Bender, J., Weigel, H.-J., Overmyer, K., et al. (2002). Activation of an oxidative burst is a general feature of sensitive plants exposed to the air pollutant ozone. Plant Cell Environ. 25, 717-726. doi: 10.1046/j.1365-3040.2002.00859.x

Xia, X.-J., Zhou, Y.-H., Shi, K., Zhou, J., Foyer, C. H., and Yu, J. Q. (2015). Interplay between reactive oxygen species and hormones in the control of plant development and stress tolerance. J. Exp. Bot. 66, 2839-2856. doi: 10.1093/jxb/ erv089

Xu, E., Vaahtera, L., and Brosché, M. (2015). Roles of defense hormones in the regulation of ozone-induced changes in gene expression and cell death. Mol. Plant 8, 1776-1794. doi: 10.1016/j.molp.2015.08.008

Yang, N., Wang, X., Cotrozzi, L., Chen, Y., and Zheng, F. (2016). Ozone effects on photosynthesis of ornamental species suitable for urban green spaces of China. Urban For. Urban Gree. 20, 437-447. doi: 10.1016/j.ufug.2016.10.014

Zhang, L., and Becker, D. F. (2015). Connecting proline metabolism and signaling pathways in plant senescence. Front. Plant Sci. 6:552. doi: 10.3389/fpls.2015. 00552

Conflict of Interest Statement: The authors declare that the research was conducted in the absence of any commercial or financial relationships that could be construed as a potential conflict of interest.

Copyright (c) 2017 Cotrozzi, Pellegrini, Guidi, Landi, Lorenzini, Massai, Remorini, Tonelli, Trivellini, Vernieri and Nali. This is an open-access article distributed under the terms of the Creative Commons Attribution License (CC BY). The use, distribution or reproduction in other forums is permitted, provided the original author(s) or licensor are credited and that the original publication in this journal is cited, in accordance with accepted academic practice. No use, distribution or reproduction is permitted which does not comply with these terms. 